\title{
First Case of Spinner Dolphin (Stenella longirostris) Infanticide off Reunion Island: Necropsy's Findings and Post Mortem Inter-Species Interactions
}

\author{
Vanessa Estrade* and Violaine Dulau \\ Globice Réunion, France
}

Submission: February 03, 2017; Published: July 03, 2017

*Corresponding author: Vanessa Estrade, Globice Réunion, 30 chemin Parc Cabris, 97410 Saint Pierre, Reunion, France, Email: vanessa.estrade@globice.org

\begin{abstract}
This paper reports the first case of delphinid infanticide off Reunion Island (Indian Ocean). This event provided a rare opportunity to record almost immediate visual and acoustic behaviour in an infanticidal context. The necropsy demonstrated that calf's death was caused by traumatical injuries, most probably inflicted through purposeful violent interactions. Teeth marks found on the calf's skin would incriminate conspecifics. However, epimeletic and in particular nurturant behaviour from a mother towards her dying calf could induce superficial tooth marks as those observed here. Post mortem acoustic and behavioural observations displayed agonistic and sexual interactions from three Indo-Pacific bottlenose dolphin males towards the mother-calf pair spinner dolphin. The nature of the inter-species interaction strongly suggests that Indo-Pacific bottlenose dolphins could have caused traumatic lethal lesions on the calf to gain sexual access to a female from a smaller species.
\end{abstract}

Keywords: Infanticide; Bottlenose dolphin; Spinner dolphin; Interaction; Tooth mark; Acoustic; behavior; Indian ocean

Abbreviations: BP: Burst Pulses; IPI: Inter-Pulse Interval; LFN: Low Frequency Narrow-band calls; PRR: Pulse Repetition Rate

\section{Introduction}

Inter-specific interactions have been recorded worldwide between different sympatric cetacean species (see [1] for a review). Although the formation of mixed-species groups may generally provide benefits for at least one of the species involved, such as foraging and/or social advantages or protection against predators [2,3], aggressive and threatening behaviours that can lead to lethal attacks have also been reported [4-7].

These negative interactions have been explained by numerous hypothetic purposes: predation or competition for prey [7-13], defensive cooperative behaviour and protection of young or ill members of the group [14-16], object-orientated play as development of predatory skills or physical training $[4,6,7,17,18]$ redirected aggression and fighting $[7,19,20]$, social pathology or aberrant behaviour [7,9] and sexually related behaviour, harassment, sexual frustration, parental manipulation, or sexual selection [4,7,9-11,19-23].

Lethal attack, and in particular infanticide, i.e. the (direct or indirect) taking of infant life, constitutes the most striking example of aggressive behaviour. This phenomenon is widely documented in the animal kingdom, including in mammals [13] and can be inflicted by both males and females $[9,13,23]$. Intra and inter-specific infanticidal events have been observed among dolphin populations [5,6,24-28], although little is known about this phenomenon. The majority of infanticides recorded in the literature involves the bottlenose dolphin (Tursiops truncatus), which, according to [29], is one of the very few marine mammals known to direct lethal, non-predatory aggression to other marine mammal species. These records have been mostly reported from post mortem examinations $[5,6,26]$ and more rarely from direct field observations $[5,25,27]$.

Reunion $\left(21^{\circ} 07^{\prime} \mathrm{S}\right.$ and $\left.55^{\circ} 32^{\prime} \mathrm{E}\right)$ is an oceanic island from the Mascarene archipelago, located about $690 \mathrm{~km}$ east of Madagascar and $170 \mathrm{~km}$ south-west of Mauritius Island. Two Delphinid species are mainly observed in coastal waters: the Indo-Pacific bottlenose dolphin (Tursiops aduncus) and the spinner dolphin (Stenella longirostris) [30]. Although Indo-Pacific bottlenose dolphins use preferentially shallower waters (generally $<60 \mathrm{~m}$ depth isobath) than spinner dolphins, the spatial distribution of the two species overlaps in some areas [31]. Mixed associations of spinner and Indo-Pacific bottlenose dolphins are regularly witnessed off the west coast [30], during which male bottlenose 
dolphins generally display sexual behaviour and harassment towards the spinner dolphins (Globice, unpub. data.).

This paper reports on the discovery of a freshly dead newborn spinner dolphin with its mother, harassed by three Indo-Pacifique bottlenose dolphins, off Saint Gilles, Reunion. This event provided a rare opportunistic occasion to put together behavioural and acoustic data on spinner/Indo-Pacific bottlenose dolphin interactions involving a dead infant, with necropsy's findings bringing evidences of infanticide.

\section{Methodologies}

\section{Context and in situ observation}

On 20th March 2016, at 1215hrs, dolphin watching operators reported the presence of a dead newborn spinner dolphin, off Saint Gilles, La Reunion. An adult individual, most probably the mother, remained close to the dead calf and a group of spinner dolphins, was observed at close distance. The mother/calf pair was closely surrounded by three Indo-Pacific bottlenose dolphins during the field observation. Underwater video from a GoPro HD Hero3 was undertaken and a 6'10" duration video clip showing dolphin behaviour was recorded.

\section{Necropsy}

The body of the dead newborn spinner dolphin was picked up from the water, transported by boat to the closest port (Saint Gilles), to be autopsied by a veterinarian from the National Stranding Network (VE). The carcass was classified as code 2 (freshly dead), according to Smithsonian Condition Codes [32] and complete necropsy, with systematic examination of all organ systems, was carried out according to standard protocols.

\section{Underwater video analysis}

The underwater video was analysed using the ad libitum sampling method, which involves reporting systematically and continuously all behavioural events observed [33]. Individual behaviours were described chronologically throughout the video session and sorted by categories (agonistic, socio-sexual or submissive) according to behaviour described in the literature (Supp. mat. S1). Particular attention was given to report on which animal was the actor or initiator of the behaviour and the recipient, when the behaviour was obviously directed towards one individual. An agonistic interaction involves "predictive signaling" in which communicative signals are produced by an initiator towards a recipient, in order to test their willingness and/or ability to escalate and fight $[34,35]$. Hence, agonistics behaviours are mostly characterized by visual and/or acoustic threat displays ([36] and Supp. mat. S1). These signals generally result in a set of either aggressive or submissive behaviours depending on the context and individual attributes of the opponent [37]. In case of aggressive response (i.e. defensive reaction), the recipient usually shows an escalation through a series of violent displays ([38] and Supp. mat. S1).
Still frames were extracted from the video and used to identify dolphins, based on the marks and scars of their dorsal fins, and were compared to the existing catalogues of the two species. When possible, photographs of the genital area were also extracted to identify the sex of the individuals, based on the presence of mammal slits and distance between anus and the uro-genital slit.

\section{Acoustic data analysis}

The acoustic recording was extracted from the video file, and converted into a .wav format. The GoPro audio sampling rate was $48 \mathrm{kHz}$. Sound types were identified by visual and aural inspection and isolated from the spectrogram display, using Raven Lite 1.0 sound analysis software. Only whistles and burst pulses were considered for analysis. Whistles-Whistles are frequency-modulated narrow-band tonal signals, usually longer than 0.1 second in duration $[39,40]$. Only loud and clear whistles, not overlapping with other sound, easily detected aurally and visually on the spectrogram were selected for analysis. Time, frequency and intensity were measured manually using the cursor functions in Raven Lite 1.0.

Eleven acoustic variables were recorded for each selected whistle : beginning frequency $(\mathrm{Hz})$, end frequency $(\mathrm{Hz})$, minimum frequency $(\mathrm{Hz})$, maximum frequency $(\mathrm{Hz})$, frequency range $(\mathrm{Hz})$, mean frequency $(\mathrm{Hz})$, start intensity $(\mathrm{dB})$, end intensity $(d B)$, number of inflexion points (i.e. the change in contour slope, from positive to negative or vice versa), duration (s) and number of harmonics. These variables were chosen to allow for comparisons with previous studies, in an attempt to identify the species producing the sound.

Burst Pulses-Burst pulse vocalizations are energetic broadband discret packets of pulsed signals produced at rates exceeding human auditory threshold allowing temporal discrimination (inter-pulse interval $<5 \mathrm{~ms}[41,42]$ ). They appear as multiple continuous harmonic bands on spectrograms [42].

Three acoustic variables were used to describe burst pulsed sounds: duration (in ms), Pulse Repetition Rate (PRR, in pulses per second or pps) and Inter Pulse Interval (IPI, in ms). The PRR, which approximates the frequency spacing between the harmonics [42], was determined by dividing the frequency range by the number of harmonics. The IPI was obtained as the inverse of the pulse repetition rate. The burst pulse emission frequency (in $\mathrm{BP} / \mathrm{min}$ ) was calculated by dividing the total number of burst pulses by the recording length. Occurrences of categorized behaviours and burst pulses events were counted throughout the time frame of the video/audio recording, and analysed in parallel in order to assess any possible link between behavioural and acoustic events.

\section{Results}

The spinner dolphin calf was discovered at the GPS position S $21^{\circ} 3^{\prime} 37^{\prime \prime}$ and E $55^{\circ} 11^{\prime} 53^{\prime \prime}$, which corresponded to a sighting 
located $2.5 \mathrm{~km}$ from the west coast of Reunion, in $60 \mathrm{~m}$ deep waters (Figure 1). The mixed species sighting was located off the west coast, in an area where spinner and Indo-Pacific bottlenose dolphin habitats overlap (Figure 1).

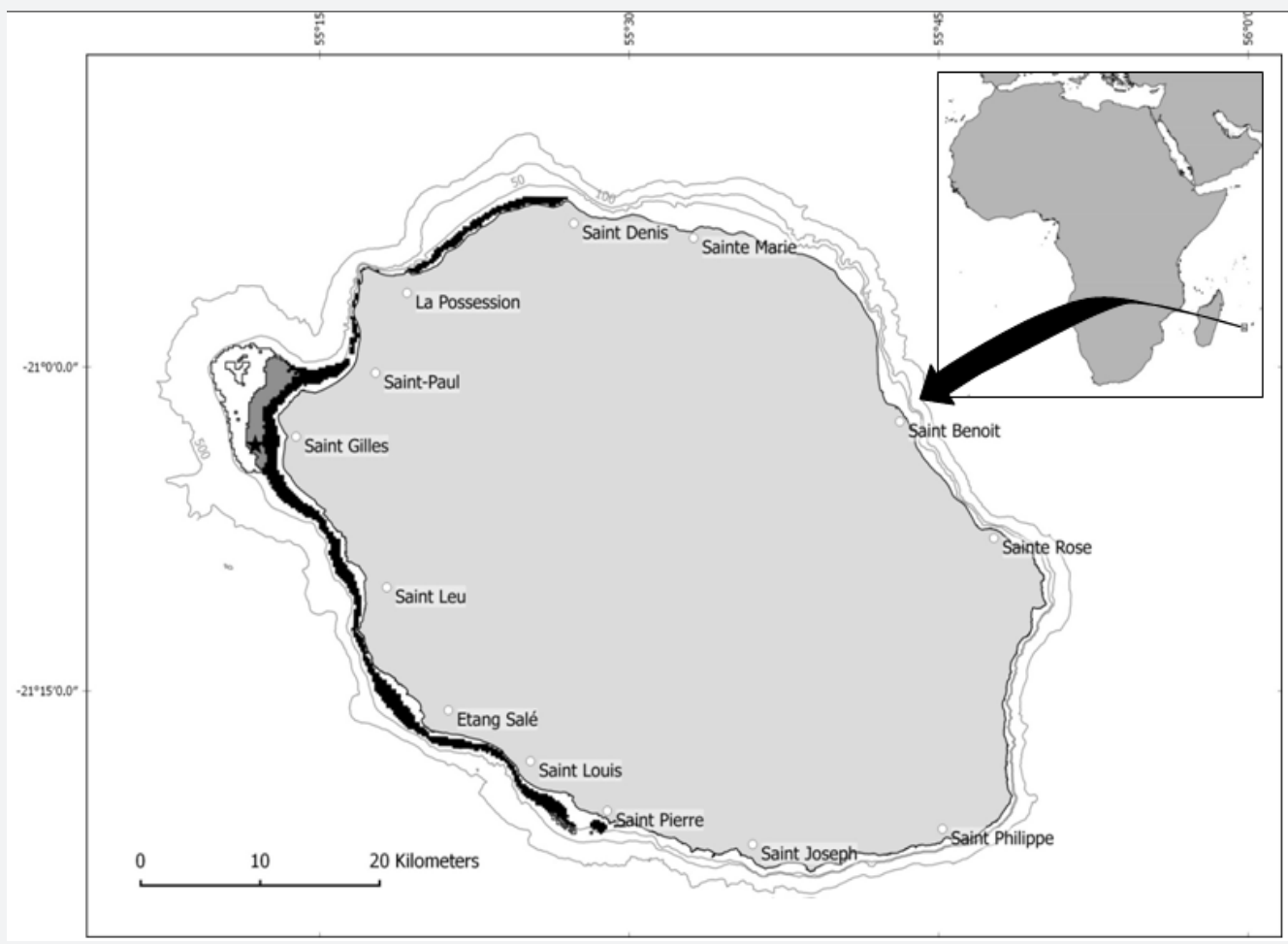

Figure 1: General view of La Reunion Island and the calf sighting (black star). Grey lines represent isobaths (100, 500 and 1000 meters). Black and white areas correspond to the suitable habitat of Indo-Pacific bottlenose and spinner dolphins, respectively [31]. These two areas overlap (grey area).
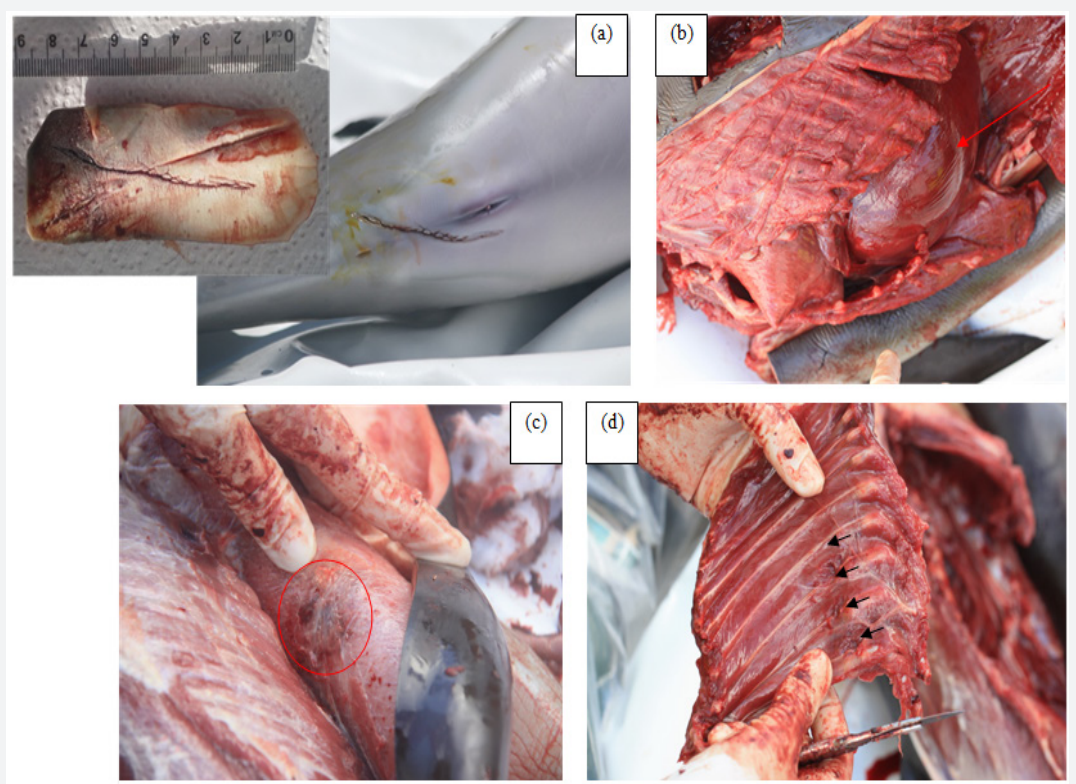

Figure 2: Lesional pattern found during the necropsy of the newborn spinner dolphin: (a) : the $7 \mathrm{~cm}$-straight-lined wound with skin punctures (b) : right pneumothorax, (c) : bruising and haemorrhage in the subcutaneous blubber layer and (d) : the linear pattern-rib fractures involving 4 adjacent ribs. Photo credit: V.Estrade. 


\section{Necropsy findings}

The newborn dolphin was $83 \mathrm{~cm}$ in length and was thus estimated to be 1-1.5 months old [43]. The age of weaning of spinner dolphins being of $1-2$ years $[43,44]$, the calf was still dependent upon its mother. The absence of teeth and the presence of milk curd found in the forestomachs corroborated its physiological status. External examination of the skin showed evidence of superficial bite wounds, not deeper than the dermis (Figure 2). A $7 \mathrm{~cm}$-long straight-lined wound between the urogenital slit and the anus and a $4 \mathrm{~cm}$-long straight-lined wound at the outer corner of the right eye exhibited numerous and evenly spaced punctures, consistent with teeth marks. The distances between each puncture ranged from 4.5 to $5.5 \mathrm{~mm}$. Gross exam of the two wounds showed slight cutaneous hemorrhage indicative that the heart was still beating when the injuries occurred. These wounds were thus made prior to the calf's death.
The necropsy displayed an healthy newborn with multiple ante mortem fatal injuries, all concentrated on the right thorax, caused by a severe blunt force trauma:

a. bruising and haemorrhage in the subcutaneous blubber layer and underlying musculature.

b. linear pattern-rib fractures, without fibrocartilagenous callus, involving 4 adjacent ribs.

c. periostal haemorrhage and rupture of adjacent lung leading to pneumothorax (Figure 2).

The cause of death was determined to be a combination of shock and respiratory difficulty consequent to unilateral pneumothorax due to fracture of the rib cage. These traumatic injuries resulting from high-energy blunt impact are consistent with infanticidal behaviour.

\section{Underwater video analysis}
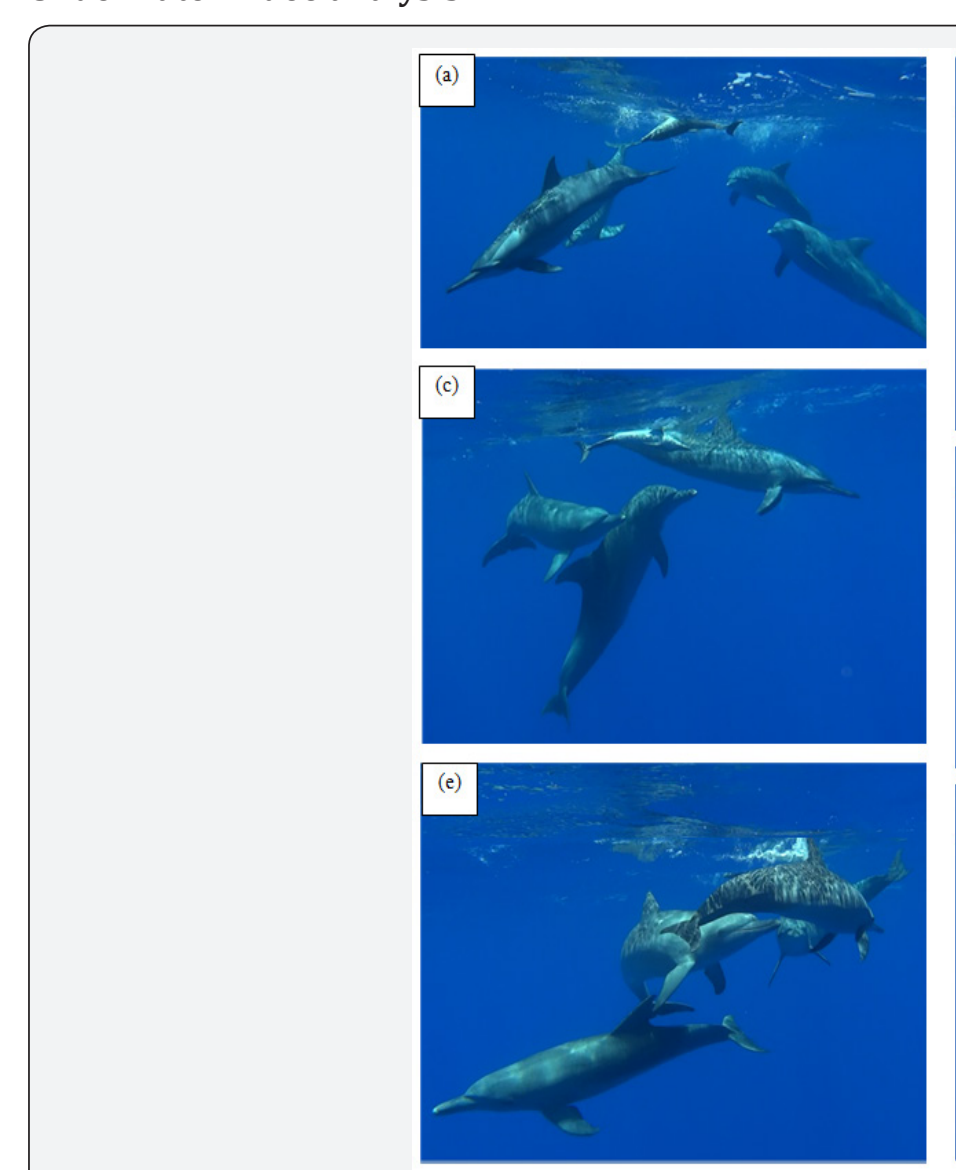
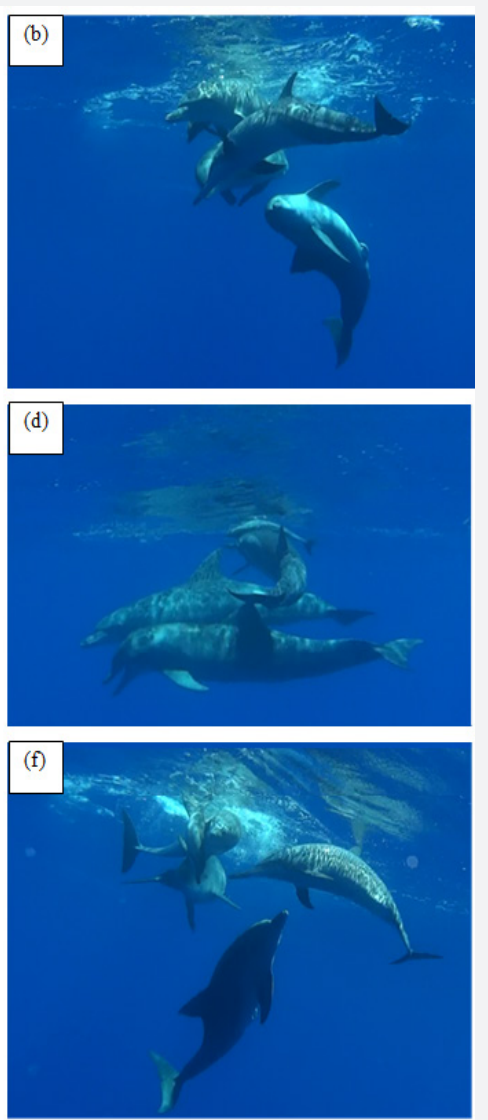

Figure 3: Agonistic and socio-sexual behavioural features : (a) : Blow bubbling from the mother spinner dolphin, pursued by the three males, (b) : penile intromission attempt from one male to the spinner dolphin mother, (c) : S-shaped posture displayed by Ta\#73 (d) : jaws opening by Ta\#305 (e) : two males pointing their rostrum towards the female and (f) : males pushing the dead newborn underwater. Photo credit: Réunion Plongée.

The 6'10" video recording displayed inter-specific interactions between three Indo-Pacific bottlenose dolphins and an adult spinner dolphin along with the body of the dead calf, floating at the surface (Figure 3). The adult spinner dolphin was identified as a female, and according to its behaviour and close proximity to the calf, was assumed to be its mother. Among the Indo-Pacific dolphins, one was about $2 / 3$ the length of the two others and lighter in color and was thus assumed to be a juvenile [45]. The juvenile was identified as a male, according to the absence of mammary slits and the distance between uro-genital 
and anal slits, and its dorsal fin was unmarked. The two other Indo-Pacific bottlenose dolphins had been previously identified as part of an ongoing photo-identification survey (Ta\#73 and Ta\#305), and were known to be males, based on molecular sexing (Globice, unpublish. data).

According to the occurrence of each categorized behaviour (i.e. agonistic, socio-sexual or submissive behaviour), the video

footage was divided into 5 distinct phases (Phases I to V - Table 1 \& Supplement material S1). Two episodes of dynamic agonistic behaviour of the 3 male Indo-Pacific bottlenose dolphins towards the female spinner dolphin were observed, which included both a moderate phase and a climax phase (Phases I and II and Phases IV and V, respectively). Theses episodeswere separated by a period of female defensive behaviour (Phase III - Table 1 \& Supplement material S1).

Table 1: Occurrence of categorized behaviours and burst pulse emission rate during the Phases I to V. The number in brackets indicates the categorized behaviour rate (i.e. number of the categorized behaviour divided by the duration of the phase ( $\min$.).

\begin{tabular}{|c|c|c|c|c|c|c|c|}
\hline & & \multicolumn{2}{|c|}{ Males } & \multicolumn{2}{|c|}{ Female } & & \\
\hline No. of Phase & Phase & $\begin{array}{l}\text { Occurrence } \\
\text { of Agonistic } \\
\text { Behaviours }\end{array}$ & $\begin{array}{l}\text { Occurrence of } \\
\text { Socio-Sexual } \\
\text { Behaviours }\end{array}$ & $\begin{array}{l}\text { Occurrence } \\
\text { of Agonistic } \\
\text { Behaviours }\end{array}$ & $\begin{array}{c}\text { Occurrence } \\
\text { of Submissive } \\
\text { Behaviours }\end{array}$ & $\begin{array}{l}\text { Duration (In } \\
\text { Minutes) }\end{array}$ & $\begin{array}{c}\text { Burst Pulse } \\
\text { Rate (In BP/ } \\
\text { Min) }\end{array}$ \\
\hline I & $\begin{array}{c}\text { Moderate } \\
\text { agonistic } \\
\text { and weak } \\
\text { socio-sexual } \\
\text { behaviours } \\
\text { phase }\end{array}$ & $18(10.6)$ & $3(1.8)$ & $2(1.2)$ & $5(2.9)$ & 1.7 & 0 \\
\hline II & $\begin{array}{l}\text { Escalation } \\
\text { phase: strong } \\
\text { agonistic and } \\
\text { socio-sexual } \\
\text { behaviours } \\
\text { phase }\end{array}$ & 73 (26.9) & $23(8.5)$ & $8(2.9)$ & $20(7.4)$ & 2.7 & 14 \\
\hline III & $\begin{array}{l}\text { Mother defense } \\
\text { phase }\end{array}$ & $1(5.0)$ & $0(0.0)$ & $2(10.0)$ & $0(0.0)$ & 0.2 & 5 \\
\hline IV & $\begin{array}{l}\text { Moderate } \\
\text { agonistic and } \\
\text { moderate } \\
\text { socio-sexual } \\
\text { behaviours } \\
\text { phase }\end{array}$ & 19 (18.4) & $7(6.8)$ & $1(1.0)$ & $6(5.8)$ & 1 & 1 \\
\hline V & $\begin{array}{l}\text { Agonistic } \\
\text { escalation } \\
\text { phase: strong } \\
\text { agonistic } \\
\text { and weak } \\
\text { socio-sexual } \\
\text { behaviours } \\
\text { phase }\end{array}$ & $16(56.5)$ & 3 (10.6) & $0(0.0)$ & $6(21.2)$ & 0.3 & 28.2 \\
\hline
\end{tabular}


Phase I was characterized by moderate agonistic and weak socio-sexual behaviours. Males were indeed engaged in various visual displays, such as deliberate head and rostrum pointing towards the female, chasing, S-shaped body posturing, faceto-face positioning, open mouth threatening, defecation and bubble blowing. In addition, weak socio-sexual gestures were noticed, with physical contact attempts initiated by males on the female (ventral side-up displays, belly-to-belly contact and body rubbing attempts against the genital region of the female).

During Phase II, a threat escalation and an increase of sexual behaviours directed to the female were observed. Indeed, in addition to agonistic and socio-sexual visual displays outlined during Phase I, hiting attempts, genital inspection, "goosing" (i.e. rubbing the rostrum against the uro-genital slot) and erection were noted. Agonistic and socio-sexual behaviours appeared to be more dynamic, frequent and intrusive than those observed in Phase I. Simultaneoulsy, more frequent submissive behaviours from the female were observed during this phase compared to Phase I.

Although the female was the agonistic target of males and mostly showed submissive reactions, she also displayed agonistic behaviours to defend herself against her « aggressors » throughout Phases II and III (Table 1 \& Supp. mat. S2). Indeed, during these phases she became more active and showed a provocative response to male harassment, with behaviours such as jaws opening or chasing against the males group. During Phase III, the female displayed solely agonistic behaviours leading to the temporary escape of the males group. Phase IV was characterized by moderate agonistic behaviours. Nevertheless, unlike Phase I, Phase IV displayed moderate sociosexual gestures involving body contact such as rostrum and body rubbing against the genital region of the female, belly-to-belly contact). Phase V showed, like Phase II, strong visual agonistic displays, with rostrum and head pointing towards the female, facing, charging and pursuing, pushing the flank of the female with rostrum, jaw opening and biting attempt. By contrast with Phase II, only weak socio-sexually related behaviours directed to the mother spinner dolphin were noted, such as head rubbing of males against the female's genital region or flank rubbing. No penis display was noticed during this phase. In parallel to males agonistic behaviours escalation, more frequent and intense submissive reactions from the female were noticed during this phase.

Supplementary material S2: Dolphins' behavioural repertoire and categorization of each behavior.

\begin{tabular}{|c|c|c|c|}
\hline & Agonistic & Socio-Sexual & Submissive \\
\hline \multirow{3}{*}{ Posture } & Head to head-facing $[29,38]$ & \multirow{3}{*}{$\begin{array}{l}\text { genital region presentation, belly } \\
\text { up }[29,58,59,60]\end{array}$} & \\
\hline & $\begin{array}{l}\text { S-shaped position; Arching the } \\
\text { head and fluke down }[46,47]\end{array}$ & & \\
\hline & $\begin{array}{l}\text { Head or rostrum pointing } \\
{[448,49,50]}\end{array}$ & & \\
\hline \multirow{3}{*}{ Body movement } & Head jerk $[51,52,53]$ & & \multirow{3}{*}{ Looking away $[37,53,64]$} \\
\hline & $\begin{array}{c}\text { Open mouth/jaw clap } \\
{[37,49,54,52,53,55,56,57]}\end{array}$ & & \\
\hline & Tail slapping $[36,57]$ & & \\
\hline \multirow{3}{*}{ Physical contact } & \multirow{3}{*}{ Biting, toothraking $[29,51,53]$} & $\begin{array}{c}\text { Gentle nipping, mouthing } \\
\text { [51,61,62] Touching, rubbing, } \\
\text { slidding the ventrum along } \\
\text { the side of other individual } \\
{[29,68,61,62] \text { Penis rubbing }} \\
{[22,60] \text { « goosing »: rostro- }} \\
\text { genital contact, Genital inspection, } \\
\text { Thrusting }[22,29,58]\end{array}$ & \\
\hline & & $\begin{array}{c}\text { Touching, rubbing, slidding the } \\
\text { ventrum along the side of other } \\
\text { individual }[29,58,61,62] \text { Penis } \\
\text { rubbing }[22,60]\end{array}$ & \\
\hline & & $\begin{array}{l}\text { " goosing » : rostro-genital } \\
\text { contact, Genital inspection, } \\
\text { Thrusting }[22,29,58]\end{array}$ & \\
\hline
\end{tabular}


Oceanography \& Fisheries Open access Journal

\begin{tabular}{|c|c|c|c|}
\hline \multirow{2}{*}{ Motion } & \multirow{2}{*}{$\begin{array}{l}\text { Chasing, charging, pursuing } \\
{[38,49]}\end{array}$} & & Flinching $[37,64,65]$ \\
\hline & & & Fleeing $[37,65]$ \\
\hline \multirow{3}{*}{ Others } & & Erection, penis display $[22,29,58]$ & \\
\hline & & Intromission attempt $[22,58]$ & \\
\hline & & $\begin{array}{c}\text { Mounting, penile intromission } \\
{[22,29,58]}\end{array}$ & \\
\hline \multirow[t]{2}{*}{ Acoustics } & \multirow{2}{*}{$\begin{array}{l}\text { Burst pulse emission, buzzing } \\
\text { [38] }\end{array}$} & LFN production & \\
\hline & & Pop vocalizations $[29,63]$ & \\
\hline
\end{tabular}

Throughout the video, the female spinner dolphin seemed to interact with her dead neonate, turning around him, pushing him with her rostrum to the surface, carrying him to the surface on her head or rubbing her back against him. Even when she tried to escape the males' pursuit, she came back rapidly towards her motionless calf. Moreover, Indo-Pacific dolphins seemed to coercively keep the mother separated from her calf, launching themselves between the mother and her calf and forcing them apart. Additionally, when the female tried to escape or returned to her offspring, the males prevented it, trapping her or encircling her obstructively. Males only interacted with the motionless body calf during Phase II. Behaviours such as ventral side rubbing or helding the calf's body underwater with the rostrum, displayed by Ta\#73 and the juvenile, were observed. pointing their rostrum towards the female and (f): males pushing the dead newborn underwater. Photo credit: Réunion Plongée

\section{Acoustic analysis}

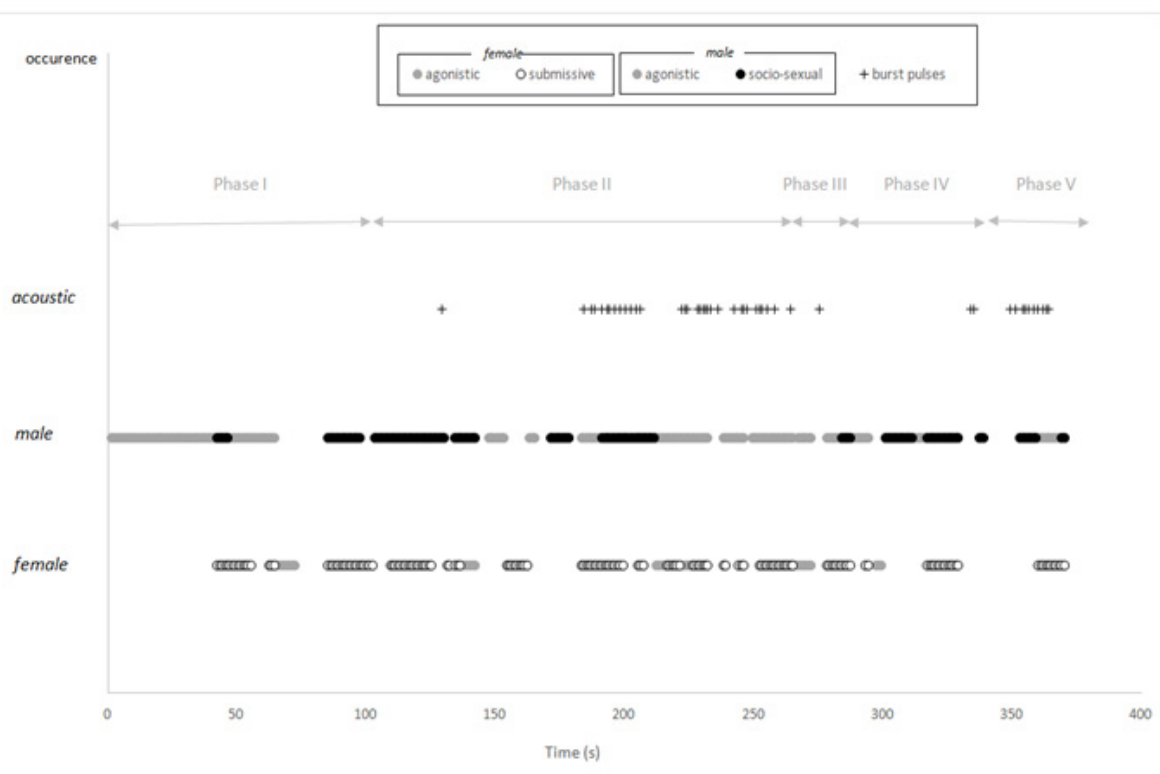

Figure 4: Parallel display of burst pulse emission events and occurrence of categorized behaviours during the video footage.

Whistles-A total of 26 whistles were aurally and visually detectable on the spectrogram including 23 whistles of high enough quality for analysis. Three types of contourwere identified (Table 2). Type I and III whistles both had sine shape; however, the type III whistle had shorter duration and displayed smaller frequency range and maximum frequency than type I. Burst Pulses-On the 66 burst pulses present on the recording, 51 were of high enough quality to be analysed. The mean duration of the burst pulses was $86.5 \pm 23.8 \mathrm{~ms}(\mathrm{n}=51)$ and the mean pulse repetition rate was $693 \pm 68$ pps $(n=49)$. The burst pulses emission frequency differed according to the behavioural phases identified in the video footage (Table 1 and Figure 4, Supplement material S1): from 0 (no burst pulse) during Phase I (moderate agonistic and weak socio-sexual behaviours phase) to $28.2 \mathrm{BP} / \mathrm{min}$. during Phase V (strong agonistic and weak sociosexual behaviours phase). The phases characterized by strong agonistic behaviours displayed highest burst pulse rate (Phase II and Phase V, with 14.0 and 28.2BP/min., respectively - see Table 2s and Figure 4). More specifically, a great proportion of burst pulse peak events coincided with males pointing their rostrum towards the female. 


\section{Oceanography \& Fisheries Open access Journal}

Table 2: Summary acoustic parameters of the three types of whistle contour recorded simultaneously to the video of spinner and Indo-Pacific bottlenose dolphin interaction.

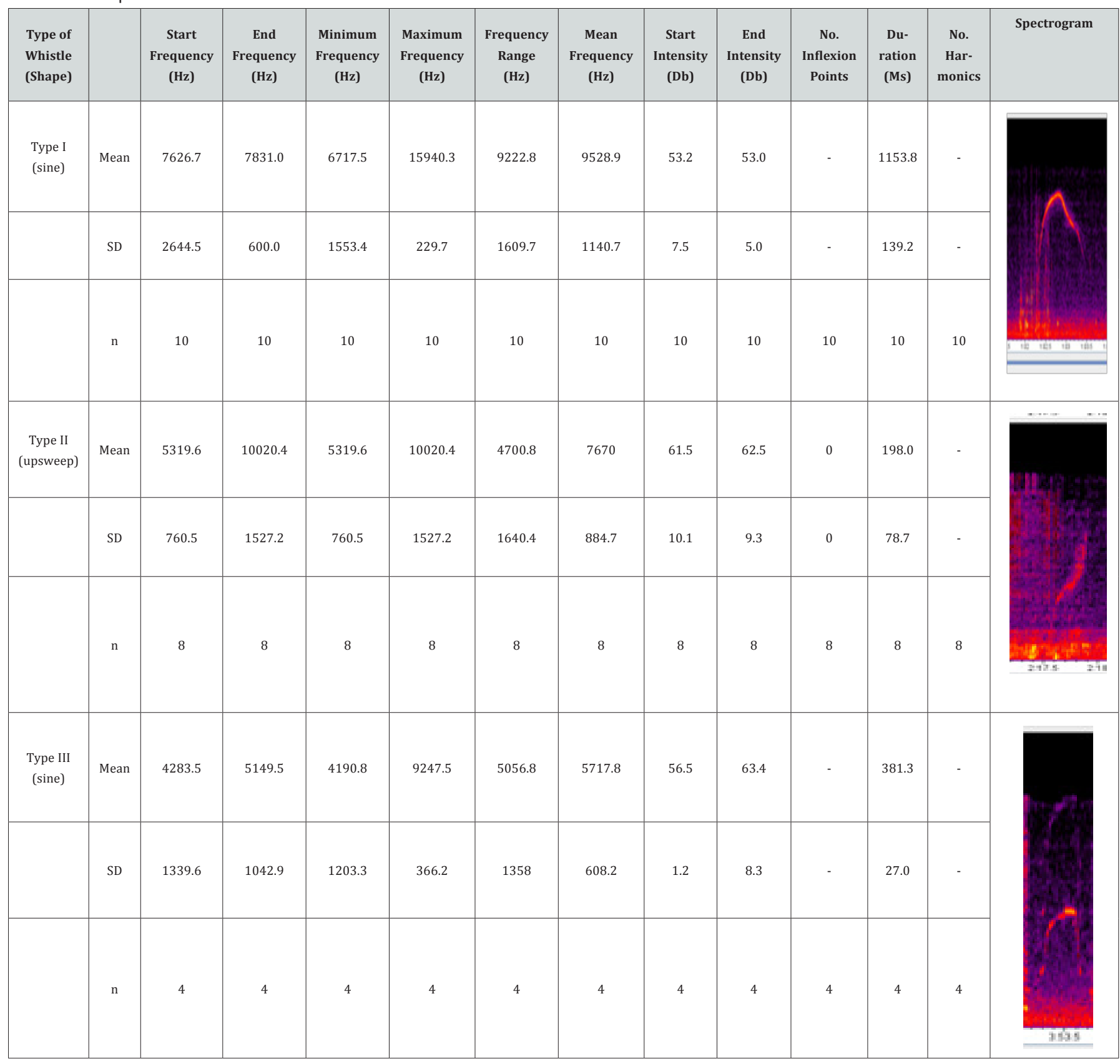

\section{Discussion}

\section{Necropsy's findings: evidence of infanticide}

The lesions described here revealed remarkable similarities with reported evidences of infanticide: presence of external bite-wound injuries, lung lacerations, adjacent rib fractures, periostal hemorrhage and bruising $[6,7,66]$. However, traumatic lesions found on the newborn spinner dolphin body seem to be less extensive and severe than described in the literature. Indeed, extensive bilateral ante mortem damages were reported from bottlenose dolphin (Tursiops truncatus) calves stranded along south eastern Virginia coasts, USA [6], within the Moray
Firth and adjacent coasts, Scotland [7] and on common dolphin (Delphinus delphis) calf stranded near Porthleven, Cornwall [25]. The injuries described were concentrated on the head and upper chest with multiple bone fractures or luxations (rib, vertebrae, scapula, mandibular, maxillary, skull, tympanic bulla...) and discrete soft tissue contusion or laceration (lung, liver, diaphragm...). [5] suggested that the lesional pattern found on carcasses (i.e. bilateral, multiple fractures and discrete soft tissues injuries) may be imputable to repeated trauma inflicted from multiple directions. In Reunion, lethal injuries were mainly concentrated on the right part of the thorax and it is likely that less violent attacks and/or lower number of 
hits were sufficient to contribute to the death of the newborn spinner dolphin, as the calf belonged to a smaller species and appeared to be younger and thus more vulnerable. Furthermore, previous studies reported lesions most likely caused by the robust bottlenose dolphin $[6,7,25]$. The lesser extent damages found on the carcass here could be imputable to a smaller and less robust delphinid species, such as the spinner dolphin or the Indo-Pacific bottlenose dolphin.

\section{Dental print of bite wounds}

The bite wounds found on the newborn skin showed punctures spaced by a 4.5 to $5.5 \mathrm{~mm}$ interval. This spacing is consistent with inter-tooth interval of Stenella $s p$. [8,27,67], suggesting that the bites were inflicted by spinner dolphin conspecifics. Tursiops sp. shows greater inter-tooth interval, of around $9.5 \mathrm{~mm}$ on average for T. aduncus (according to skull measurements and number of teeth data from [68]) and between 10.9 and $12.3 \mathrm{~mm}$ for T. truncatus [8].

The presence of bite wounds caused by spinner dolphins bears witness to intra-specific interactions of spinner dolphins towards the newborn calf, but does not mean that this interaction is responsible for the death, especially as wounds were superficial. In general, the presence of rake marks on cetaceans is interpreted as the result of aggressive interaction $[69,70]$. However, some researchers have concluded that epimeletic behaviour can lead to rake marks [71-74]. Epimeletic or caregiving behaviour is defined as the help given from an individual to another. In particular, when attention is directed by a healthy adult, generally the mother, towards her sick, injured or dead calf, it corresponds to "nurturant" behaviour $[16,75]$. The behaviour displayed by the female spinner dolphin towards her dead neonate, i.e. carrying him on her head and pushing him to the surface with the rostrum, resembled that described in other papers [71-80]. Moreover, the superficial nature of the wounds suggests that they would result from manipulation of the body rather than from a bite, which would undoubtedly lead to more damages. It seems thus likely that the mother displayed an epimeletic behaviour towards her dying offspring and that she was responsible for tooth marks on his body. Because wounds found on calf's body were made ante mortem, the female might have inflicted them to the calf before death, in an attempt to help him or keep him away from the aggressors.

\section{Inter-specific interactions: agonistic and socio/sexual behaviour of indo-pacific bottlenose dolphins}

The video footage displayed agonistic, socio-sexual interactions from the three Indo-Pacific bottlenose dolphin males towards the mother spinner dolphin, around the floating calf's corpse. Aggressive behaviour, such as bite or ramming, likely to cause harm, was not observed during the 6 min recording and the moderate violence level of this recorded interaction is consistent with an agonistic display between the two species. Nonetheless, the available video footage represented only part of the inter-specific interaction and it cannot be excluded that more aggressive behaviours occurred. Dolphin-watching operators reported that the 3 male bottlenose dolphins were observed among the group of spinner earlier in the morning, harassing a mother with calf, suggesting that the inter-specific interaction lasted for several hours.

Inter-specific negative interactions involving Tursiops genus have been widely observed [7-9,22,23,66,81-85]. In Reunion, mixed association between spinner and Indo-Pacific bottlenose dolphins are regularly witnessed (about 10\% of spinner dolphins' sightings) [30]. In particular, most of these sightings involves male Indo-Pacific bottlenose dolphins (generally including Ta\#305) engaged in sexual harassment of female spinner dolphins (Globice, unpub. data). Throughout the video recording, and especially during Phase II (escalation phase: strong agonistic and socio-sexual behaviours phase), the three bottlenose dolphins showed sexually related displays including gentle physical contacts (rubbing, ...), genital inspection, ventral side-up swimming and erection. This behaviour was consistent with the social structure of T. aduncus, in which males form alliances to herd females for sexual or reproduction purposes [58,86-89]. This cooperative behaviour allows males to enforce and maintain consortships with females [87] and mate through sexual coercion $[86,88]$.

\section{Acoustic behaviour}

The presence of burst pulses in the recording session corroborates the agonistic and/or socio-sexual nature of the interaction observed. Several studies documented broadband burst pulsed sounds to be associated with social context such as aggressive/agonistic interactions among captive dolphins $[38,48,49,90]$. Similarly, in free-ranging dolphins, burst pulsed vocalizations have been attributed to aggressive behaviour and courtship [21,38,54,91-95]. The mean burst pulse emission frequency was 10.7 burst pulses/min, which is comparable to what we can find in the literature (8.0 burst pulses/min - [95]). Pulse repetition rate (PRR) and inter-pulse interval (IPI) did not allowed to discrimate between the two species, as values were consistent with both spinner dolphins $[93,96]$ and bottlenose dolphins [97]. However, intensive burst pulsed sounds and increased burst pulse emission frequency were observed simultaneously with high intensity agonistic behaviour during Phases II and V, suggesting that emission frequency increased according to the excitation level [48]. More specifically, the emission of pulsed sounds coincided with males pointing their rostrum towards the female. This posture may be deliberately adopted by aggressors to ensure that maximum energy sound reaches the targeted individual $[48,50]$. Therefore, it is believed that burst pulse sounds were produced by male bottlenose dolphins towards the female spinner dolphin.

Similarly, comparison of acoustic parameters of each whistle contour with those found in the literature for Indo-Pacific bottlenose [50,97-101] and spinner dolphins [50,93-105] 
did not allow to determine which species was producing the sounds. However, the most frequent whistle recorded was type I (sine shape), which showed a distinct and repetitive contour and was produced in bouts of 1-2 whistles. The predominance, stereotypic nature and complex sine shape of this whistle type is consistent with a signature whistle $[106,107]$. Signature whistles are believed to convey the identity of both the caller and the group it belongs to [108-112] and are produced predominantly in circumstances of social separation, isolation or stressful situation [107,109,113-115]. As the mother spinner dolphin was kept coercively from her dead calf by the three males and probably apart from the spinner dolphins group observed nearby, it is likely that the signature whistle recorded belong to the female spinner dolphin in distress.

\section{Possible causes of Infanticidal behaviour and species involved}

Necropsy made on the freshly dead calf attributed the cause of death to blunt-force trauma, providing strong evidence for infanticide. Although the lethal interaction was not directly observed, post mortem acoustic and behavioural observations tend to be in favor of an inter-species infanticide of Indo-Pacific bottlenose dolphin on spinner dolphin. Most infanticide events reported worldwide involve bottlenose dolphins (T. truncatus) either on conspecifics $[6,7,95]$ or towards another species $[25,29]$, so this behaviour appear to be part of the natural habits of Tursiops sp., although never reported from T. aduncus. To our knowledge, infanticides among spinner dolphins and more generally the genus Stenella have not been reported previously. The nature of the inter-species interaction between bottlenose and spinner dolphin observed right after, and probably before the calf death (as reported by operators, but not captured in video) made the interpretation of inter-specific infanticide most likely. Furthermore, the necropsy indicated that the newborn was physically healthy (no pathology, malformation or other sign of weakness reported), which tend to rule out the hypothesis that the calf was killed by conspecific because of its low probability of survival.

Given the agonistic and socio/sexual behaviour of the 3 male Indo-Pacifique bottlenose dolphins towards the mother spinner dolphin, several hypothesis could be put forward, among those that have been previously proposed to explain infanticides $[5,24,25,29]$. Males may commit infanticide to gain sexual access to the female, both for recreational and procreative sex $[6,7,24,116]$, especially when access to females is limited.

Infanticide may represent a male reproductive strategy whereby males kill the offspring of competing males in order to increase their own reproductive success [24,117-119]. Furthermore, when a female loses her dependent offspring prematurely, she soon becomes sexually receptive to males within a few days $[24,120]$. Infanticide could thus appear as a strategy to enhance reproductive success of males by inducing estrous in females that would otherwise be reproductively unavailable [121], hence allowing males to increase their breeding opportunities and ensure the transmission of their own genetic pool. Inter-specific mating has been described among cetaceans and often involves Tursiops genus in the wild $[5,22,23,61,122,123]$. To our knowledge, bottlenose X spinner dolphin hybrid has not yet been described neither in captive nor within free-ranging dolphins, although Tursiops genus exhibits great mating behavioural plasticity relative to other species (reviewed in [124]) and has succeeded in breeding with genetically more distant species such as the Risso's dolphin, the short-finned pilot whale and the false killer whale [125-129].

Alternatively, infanticide and socio/sexual behaviour on a smaller species may have resulted from sexual frustration of male Indo-Pacific bottlenose dolphins. In Reunion, although the sex ratio is unknown, the small size of the Indo-Pacific bottlenose dolphin population Dulau et al. [30] in prep.) might lead to a relatively low availability of receptive females and males might turn to other sympatric species, such as spinner dolphins, to exercice sexual behaviour. Sexual frustration and aggressive behaviour might also be triggered by increase levels of testosterone during the breeding season [121,130,131]. Although no clear peak of reproductive activity have been identified in Reunion, the infanticide occurred in austral summer (March), thus during the breeding season reported for the species [132].

Furthermore, the presence of a juvenile among the male bottlenose dolphin could suggest that adult males were providing sexual behaviour learning to the young, thereby providing him visual displays for mimetism and mating practice, while reinforcing collaboration within male alliance $[23,133,134]$. In fact, an isolated female belonging to a smaller species would represent a good opportunity for young males to develop their own sexual experience and practice herding of females.

\section{Conclusion}

This is the first report of infanticide from Reunion Island and to date, it is not possible to determinate if this represents a single isolated event or if it occurs on more regular basis, yet being unobserved. In future projects, further attention should be given to aggressive interactions involving IndoPacific bottlenose dolphins, particularly if a calf is engaged, in order to investigate whether infanticide behaviour could have conservation implications. Indeed, infanticide events may result from stochastic variation in population sex ratio or disruption of social bonds due to anthropic disturbance and habitat alterations and even climate change $[20,122,135]$. In turn, this behaviour could have serious impacts on population demography and viability [135], especially on small resident cetacean population [7].

\section{Acknowledgement}

We are grateful to dolphin watching operators Croisières \& Découvertes for having reported this event to Globice Réunion. 
We are also thankful to Réunion Plongée for recording the video clip of the inter-specific interaction. The necropsy was carried out according to the (French) National Stranding Network protocol, under the aegis of Observatoire Pelagis, La Rochelle, France, and funded by the Conseil Regional- Reunion.

Supplementary material S1: The chronology of the individuals' behaviours throughout the video recording session. The behaviours in bold belong to the agonistic/ socio-sexual repertoire of dolphins, while behaviours in italic correspond to mother's acts towards her dead offspring.

\begin{tabular}{|c|c|c|}
\hline Time From Beginning & Phase and Burst Pulse Rate & Observations \\
\hline $00: 00$ to $00: 14$ & \multirow{11}{*}{$\begin{array}{l}\text { Phase I "moderate agonistic and weak socio- } \\
\text { sexual behaviours phase" No burst pulses }\end{array}$} & $\begin{array}{l}\text { The mother interacted with her offspring, and } \\
\text { turned around him. The three males swim } \\
\text { around the mother/calf pair. }\end{array}$ \\
\hline $00: 14$ to $00: 32$ & & $\begin{array}{l}\text { Ta\#73 stayed in a arched position. Ta\# } 305 \text { and } \\
\text { the juvenile kept turning around the mother/ } \\
\text { calf pair while the female rotate fastly around } \\
\text { the calf. Then the juvenile stayed closer to the } \\
\text { newborn, and finally moved away to remain on } \\
\text { the sidelines. }\end{array}$ \\
\hline $00: 32$ to $00: 41$ & & $\begin{array}{l}\text { Males rotated around the stationary female } \\
\text { spinner dolphin. }\end{array}$ \\
\hline $00: 41$ to $00: 46$ & & $\begin{array}{l}\text { The juvenile upward pointed his rostrum } \\
\text { towards the mother, and attempted a belly-to- } \\
\text { belly contact with the mother. Ta\# } 305 \text { swam in } \\
\text { a circular pattern. The female suddenly turned } \\
\text { through the neonate, trying to escape her } \\
\text { aggressors. }\end{array}$ \\
\hline $00: 46$ to $00: 55$ & & $\begin{array}{l}\text { Ta\#305 and Ta\#73 faced the mother. Any } \\
\text { attempts by the mother to escape was } \\
\text { prevented by the juvenile that blocked her. The } \\
\text { female finally displayed rapid swimming to her } \\
\text { offspring. }\end{array}$ \\
\hline $00: 55$ to $01: 01$ & & $\begin{array}{l}\text { The mother stayed close to the neonate. The } \\
\text { two adult males turned back to the female in } \\
\text { tight association while the juvenile remained } \\
\text { away. Ta\# } 73 \text { defecated. }\end{array}$ \\
\hline $01: 01$ to $01: 04$ & & $\begin{array}{l}\text { The two adult males chased the mother, which } \\
\text { accelerated and attempted to escape. She } \\
\text { finally faced her aggressors to reach the calf's } \\
\text { body. Ta\#\#305 threatened the female by open } \\
\text { mouthing. }\end{array}$ \\
\hline $01: 04$ to $01: 12$ & & $\begin{array}{l}\text { The three males stayed stationary below the } \\
\text { female that displayed a S-shaped body posture. }\end{array}$ \\
\hline $01: 18$ to $01: 21$ & & $\begin{array}{l}\text { The mother stayed close to her neonate while } \\
\text { Ta\# } 305 \text { and Ta\# } 73 \text { moved away in an close } \\
\text { association, and the juvenile stayed alone, } \\
\text { farther from the female. }\end{array}$ \\
\hline $01: 25$ to $01: 37$ & & $\begin{array}{l}\text { The mother kept staying close to the body. The } \\
\text { juvenile swam towards the female/calf pair, } \\
\text { displayed ventral side-up, and attempt to rub } \\
\text { his body against the genital area of the female. } \\
\text { The female tried to escape and turned around } \\
\text { the calf. The juvenile blew bubbles. }\end{array}$ \\
\hline $01: 37$ to $01: 42$ & & $\begin{array}{l}\text { The juvenile moved away, while the female } \\
\text { displayed rapid swimming, surrounding the } \\
\text { calf. }\end{array}$ \\
\hline
\end{tabular}




\begin{tabular}{|c|c|c|}
\hline $01: 42$ to $01: 48$ & \multirow{10}{*}{$\begin{array}{l}\text { Phase II " escalation phase: strong agonistic } \\
\text { and socio-sexual behaviours phase " Burst } \\
\text { pulses emission frequency }=14.0 \mathrm{BP} / \mathrm{min} \text {. }\end{array}$} & $\begin{array}{l}\text { Ta\#305 and Ta\#73 swam fastly in direction } \\
\text { of the female, in tight association. Ta\#73 } \\
\text { positioned himself beneath the mother and } \\
\text { rubbed his ventral side against the female and } \\
\text { the offspring's dead body. The female was then } \\
\text { caught between the two adult males. }\end{array}$ \\
\hline $01: 48$ to $01: 57$ & & $\begin{array}{l}\text { The female turned back to her neonate. The } \\
\text { two adult males rotated towards the female/ } \\
\text { calf pair, with Ta\#305 in first position, and } \\
\text { Ta\# } 73 \text { slightly behind. Ta\#305, in turn, swam } \\
\text { towards the female, the ventral side-up. The } \\
\text { female attempted to escape, swam rapidly } \\
\text { and turned fastly around the offspring, while } \\
\text { Ta\#73 stayed stationary, close to the scene, in } \\
\text { an horizontal position. The juvenile rushed at } \\
\text { the female, blowing bubbles. }\end{array}$ \\
\hline $01: 57$ to $02: 05$ & & $\begin{array}{l}\text { The three males associated into close coalition, } \\
\text { with Ta\#305 still showing his belly side, and } \\
\text { the juvenile swimming on the left flank. They } \\
\text { chased the female, which tried to escape and } \\
\text { accelerated, turning around the calf's body. }\end{array}$ \\
\hline $02: 05$ to $02: 08$ & & $\begin{array}{l}\text { While Ta\#305 and Ta\#73 stayed tightly } \\
\text { associated behind the female, the juvenile } \\
\text { moved away, and then came back, positioned } \\
\text { himself with his ventral side-up, and displayed } \\
\text { an obvious erection. The two adult males } \\
\text { positioned themselves vertically, into a } \\
\text { S-shaped-like position, and pushed their } \\
\text { rostrum against the mother's body, while the } \\
\text { female turned around her calf. }\end{array}$ \\
\hline $02: 08$ to $02: 10$ & & $\begin{array}{l}\text { Ta\#73 stayed into a vertical stationary position, } \\
\text { with an extroverted penis, pushing the calf's } \\
\text { body with his rostrum. Ta\# } 305 \text { and the juvenile } \\
\text { swam towards the female in close proximity. }\end{array}$ \\
\hline $02: 10$ to $02: 12$ & & $\begin{array}{l}\text { The female accelerated to escape the three } \\
\text { males group, merged into a close association, } \\
\text { with the juvenile between Ta\# } 305 \text { and Ta\# } 73 \text {, } \\
\text { and Ta\#305 lying on his right flank. }\end{array}$ \\
\hline $02: 13$ to $02: 16$ & & $\begin{array}{l}\text { The juvenile, in erection, held the calf's body } \\
\text { underwater with his rostrum, while Ta\# } 73 \\
\text { stayed behind, in tight bond with the juvenile. } \\
\text { The mother firstly escaped, then came back to } \\
\text { her offspring, while Ta\# } 305 \text {, into an arched } \\
\text { position and in erection, upward pointed his } \\
\text { rostrum and surfaced towards the female. The } \\
\text { mother accelerated to avoid the contact. }\end{array}$ \\
\hline $02: 16$ to $02: 22$ & & $\begin{array}{l}\text { The juvenile rubbed his pectoral fins against } \\
\text { the female's head. The female arched her body } \\
\text { while Ta\#73 and Ta\# } 305 \text { approach her, with } \\
\text { Ta\#305 in erection. Ta\# } 73 \text { rubbed his belly } \\
\text { side against the mother's uro-genital area, } \\
\text { and then swam away. Finally, Ta\# } 305 \text { surfaced } \\
\text { towards the mother and swam in parallel. } \\
\text { Ta\#73 defecated. }\end{array}$ \\
\hline $02: 22$ to $02: 26$ & & $\begin{array}{l}\text { The mother returned towards her neonate, and } \\
\text { the three males swam calmly around the pair. }\end{array}$ \\
\hline $02: 26$ to $02: 33$ & & $\begin{array}{l}\text { The three Indo-Pacific bottlenose dolphins } \\
\text { approach the female, stayed stationary close to } \\
\text { the calf, and surrounded the spinner dolphins' } \\
\text { pair. }\end{array}$ \\
\hline
\end{tabular}




\begin{tabular}{|c|c|}
\hline $02: 33$ to $02: 42$ & $\begin{array}{l}\text { The female attempt to get away, defecated, and } \\
\text { then return to her offspring, pushing him with } \\
\text { her rostrum. The three male swam calmly one } \\
\text { body-length around the mother/calf pair. }\end{array}$ \\
\hline $02: 42$ to $02: 45$ & $\begin{array}{l}\text { Ta\#73 surfaced between the mother and her } \\
\text { calf. }\end{array}$ \\
\hline $02: 51$ to $02: 58$ & $\begin{array}{l}\text { The female stood vertically close to the calf, } \\
\text { pushing him with her rostrum. Ta\# } 73 \text { and the } \\
\text { juvenile swam towards the mother/calf pair. } \\
\text { The juvenile rubbed his right flank against the } \\
\text { belly side of the mother, always displaying a } \\
\text { vertical position. Ta\# } 73 \text { and Ta\# } 305 \text { swam and } \\
\text { pointed their rostrum towards the female. }\end{array}$ \\
\hline $03: 03$ to $03: 10$ & $\begin{array}{l}\text { Ta\# } 73 \text { and Ta\#305 turned around the female, } \\
\text { still in vertical position near her calf. Ta\# } 73 \\
\text { approached the mother, upward pointing } \\
\text { his rostrum in her direction. The mother } \\
\text { accelerated to escape, and then came back to } \\
\text { her infant, facing and trying to avoid Ta\#73. }\end{array}$ \\
\hline $03: 10$ to $03: 16$ & $\begin{array}{l}\text { The female rubbed her back against the calf's } \\
\text { body. Ta\#73 swam towards the mother and } \\
\text { rubbed his head against the head and then } \\
\text { the uro-genital area of the mother while the } \\
\text { juvenile stayed into echelon position, and } \\
\text { Ta\#305 swam calmly around. The female } \\
\text { managed to free from Ta\#73's contact and } \\
\text { returned fastly closer to her offspring. }\end{array}$ \\
\hline $03: 16$ to $03: 19$ & $\begin{array}{l}\text { Ta\#305 pursued the female, which showed } \\
\text { rapid movements to escape, and went away } \\
\text { from the calf. Ta\# } 305 \text { reached her and rubbed } \\
\text { his rostrum against the mother's uro-genital } \\
\text { slot. Ta\# } 73 \text { remained away, stationary. }\end{array}$ \\
\hline $03: 19$ to $03: 24$ & $\begin{array}{l}\text { The mother returned close to the calf and } \\
\text { pushed him with the rostrum, while Ta\# } 73 \\
\text { swam towards the female, on the right flank, } \\
\text { and rubbed his rostrum against the uro-genital } \\
\text { area of the mother. }\end{array}$ \\
\hline $03: 24$ to $03: 27$ & $\begin{array}{l}\text { The three males approached behind the female } \\
\text { in a coalitional formation. The mother initially } \\
\text { staying near the neonate, and then, fastly swam } \\
\text { away, pursued by the coalition. She returned } \\
\text { rapidly through the neonate, faced to and then } \\
\text { circumvented the males. }\end{array}$ \\
\hline $03: 27$ to $03: 31$ & $\begin{array}{l}\text { Ta\#305 initiated pursuing the mother, and } \\
\text { Ta\#73 approached her on the opposite side, } \\
\text { preventing her from swimming to the calf. } \\
\text { Ta\#305 kept pursuing the female, trying to } \\
\text { touch her with his rostrum. }\end{array}$ \\
\hline $03: 31$ to $03: 35$ & $\begin{array}{l}\text { The two adult males swam slowly around the } \\
\text { female, which displayed an arched posture } \\
\text { near the calf. Ta\# } 305 \text { lied on his right flank } \\
\text { beneath the female, and surfaced, pointing his } \\
\text { rostrum in direction of the female. }\end{array}$ \\
\hline $03: 35$ to $03: 41$ & $\begin{array}{l}\text { Ta\#73 and Ta\#305 flanked the mother, the } \\
\text { juvenile remained away from the group. The } \\
\text { female attempted to escape, swam rapidly and } \\
\text { then turned in direction to the calf. }\end{array}$ \\
\hline $03: 41$ to $03: 45$ & $\begin{array}{l}\text { The three males swam calmly around the } \\
\text { mother/calf pair. The mother displayed a } \\
\text { S-shape position. Ta\# } 73 \text { remained stationary, } \\
\text { vertically, parallel and close to the pair, while } \\
\text { Ta\# } 305 \text { surfaced, head pointed through the } \\
\text { female. }\end{array}$ \\
\hline
\end{tabular}




\begin{tabular}{|c|c|}
\hline $03: 45$ to $03: 50$ & $\begin{array}{l}\text { The female was then trapped between Ta\#305 } \\
\text { and Ta\#73, and swam fastly away from this } \\
\text { pair, pursued by the juvenile and Ta\#305. } \\
\text { Ta\#305 opened his jaws during the pursuit. } \\
\text { The female turned around the neonate while } \\
\text { Ta\#73 stayed in an arched position, one body- } \\
\text { length beneath the female. }\end{array}$ \\
\hline $03: 50$ to $03: 52$ & $\begin{array}{l}\text { Ta\#73 left his static posture and associated } \\
\text { with Ta\#305 and faced the female who escaped } \\
\text { the two males swimming faster. The juvenile } \\
\text { remained away from the group. Then Ta\# } 305 \\
\text { pursued the female, opening his mouth, } \\
\text { followed by Ta\# } 73 \text { and the juvenile. The female } \\
\text { turned in depth to avoid her aggressors. }\end{array}$ \\
\hline $03: 52$ to $03: 57$ & $\begin{array}{l}\text { Ta\#73 stayed near the calf while the two } \\
\text { other males swam slowly farther. The female } \\
\text { returned closer to the newborn. }\end{array}$ \\
\hline $03: 57$ to $03: 59$ & $\begin{array}{l}\text { Ta\#305 and the juvenile swam together, } \\
\text { pursuing the mother. Ta\# } 73 \text { stayed in a vertical } \\
\text { position, near the calf. The female left her calf } \\
\text { to escape the males. }\end{array}$ \\
\hline $03: 59$ to $04: 03$ & $\begin{array}{l}\text { Ta\#305 pursued the female, followed by the } \\
\text { juvenile. Ta\# } 73 \text { left his position. The female } \\
\text { turned to reach her offspring. }\end{array}$ \\
\hline $04: 03$ to $04: 06$ & $\begin{array}{l}\text { The female tried to escape the three males } \\
\text { diving deeper, but the males swam towards } \\
\text { her, associating and all pointing their rostrum } \\
\text { towards the mother. Ta\# } 305 \text { opened his jaws in } \\
\text { direction of her, trying to hit her fluke when the } \\
\text { mother swam close. She then surfaced fastly to } \\
\text { reach her calf. }\end{array}$ \\
\hline $04: 06$ to $04: 08$ & $\begin{array}{l}\text { The mother dived, slowly followed by Ta\#305 } \\
\text { and farther, Ta\# } 73 \text {. The juvenile remained on } \\
\text { the sidelines. The three males associated and } \\
\text { swam calmly behind the female that turned } \\
\text { diving deeper. }\end{array}$ \\
\hline $04: 08$ to $04: 11$ & $\begin{array}{l}\text { Ta\#305 kept swimming towards the calf. } \\
\text { Ta\#73 and the juvenile remained into an } \\
\text { horizontal position in a tight association, above } \\
\text { the female. Ta\# } 73 \text { showed downward-pointing } \\
\text { head posture and opened the mouth towards } \\
\text { the passing female. Then the female returned } \\
\text { close to her offspring, and so, reached Ta\#305. }\end{array}$ \\
\hline $04: 11$ to $04: 16$ & $\begin{array}{l}\text { Ta\#305 swam and turned slowly in parallel } \\
\text { to the mother, forcing her to turn in the same } \\
\text { direction. Finally, the mother dived deeper, } \\
\text { followed by Ta\#305, downward pointing her } \\
\text { with his rostrum, and the Ta\# } 73 / \text { juvenile pair } \\
\text { remained away in a S-shaped position. The } \\
\text { female escaped slowly from Ta\#305, and blew } \\
\text { bubbles. }\end{array}$ \\
\hline $04: 16$ to $04: 25$ & $\begin{array}{l}\text { The female surfaced and turned through } \\
\text { her calf and then pointed her head towards } \\
\text { Ta\#305, while he dived deeper. The juvenile } \\
\text { / Ta\#73 pair stayed in the arched position } \\
\text { close to the calf. They surfaced in front of the } \\
\text { neonate and then dived towards the mother } \\
\text { that circumvented them to reach her offspring. } \\
\text { The two males (Ta\#73 and the juvenile) } \\
\text { blew bubbles while swimming away from } \\
\text { the female/calf pair. Ta\#305 joined the male } \\
\text { escaping group. }\end{array}$ \\
\hline
\end{tabular}




\begin{tabular}{|c|c|c|}
\hline $04: 25$ to $04: 26$ & \multirow{3}{*}{$\begin{array}{l}\text { Phase III "mother defense phase" Burst pulses } \\
\text { emission frequency }=5.0 \mathrm{BP} / \mathrm{min} \text {. }\end{array}$} & $\begin{array}{l}\text { The female stayed stationary near her calf, } \\
\text { downward pointed her rostrum towards the } \\
\text { escaping group. }\end{array}$ \\
\hline $04: 26$ to $04: 32$ & & $\begin{array}{l}\text { The mother left her calf and swam to the three } \\
\text { male group, separated into the adult male pair } \\
\text { and the juvenile, farther. Ta\# } 305 \text { swam away } \\
\text { blowing bubbles. The female turned then } \\
\text { through the neonate. }\end{array}$ \\
\hline $04: 32$ to $04: 37$ & & $\begin{array}{l}\text { The mother, alone with her calf, pushed him } \\
\text { to the surface with her rostrum. The juvenile } \\
\text { swam slowly to the female/newborn pair and } \\
\text { then dived. }\end{array}$ \\
\hline $04: 37$ to $04: 43$ & \multirow{8}{*}{$\begin{array}{l}\text { Phase IV "moderate agonistic and moderate } \\
\text { socio-sexual behaviours phase" Burst pulses } \\
\text { emission frequency }=1.0 \mathrm{BP} / \mathrm{min} \text {. }\end{array}$} & $\begin{array}{l}\text { The juvenile joined the two adult males } \\
\text { swimming towards the mother/calf pair. The } \\
\text { mother initially stationary in close proximity to } \\
\text { her offspring, slightly accelerated and turned } \\
\text { away. The Ta\# } 73 \text { / Ta\# } 305 \text { pair, in echelon } \\
\text { position approached the female, and turned } \\
\text { slowly towards her. The juvenile remained } \\
\text { away. }\end{array}$ \\
\hline $04: 43$ to $04: 47$ & & $\begin{array}{l}\text { Ta\#73 surfaced near the calf while Ta\#305 kept } \\
\text { pursuing the mother. He reached her while she } \\
\text { fastly turned towards the calf. Ta\# } 305 \text { pointed } \\
\text { his rostrum towards the mother trying to rub } \\
\text { her genital slot. The female circumvented } \\
\text { Ta\#305 to join her calf, in parallel to Ta\#73. } \\
\text { Ta\#305 dived. }\end{array}$ \\
\hline $04: 47$ to $04: 52$ & & $\begin{array}{l}\text { Ta\# } 73 \text { remained in an horizontal position, near } \\
\text { the female/calf pair. Ta\# } 305 \text { swam towards } \\
\text { the trio, and pointed his rostrum towards the } \\
\text { female, who pushed her calf with the rostrum. }\end{array}$ \\
\hline $04: 52$ to $04: 54$ & & $\begin{array}{l}\text { The two adult males surrounded and flanked } \\
\text { the female, pointing their rostrum towards her, } \\
\text { resulting in the female escape. }\end{array}$ \\
\hline $04: 57$ to $04: 59$ & & $\begin{array}{l}\text { The female displayed the S-shaped posture. } \\
\text { The two adult males left the female. }\end{array}$ \\
\hline $05: 01$ to $05: 11$ & & $\begin{array}{l}\text { Ta\#73 returned slowly close to the mother, } \\
\text { defecated and opened his mouth. He upward- } \\
\text { pointed his rostrum towards the mother, and } \\
\text { rubbed his rostrum against her belly side, } \\
\text { while the mother remained stationary in the } \\
\text { surface, near her calf. Ta\#305 swam away, and } \\
\text { then dived. }\end{array}$ \\
\hline $05: 11$ to $05: 16$ & & $\begin{array}{l}\text { Ta\#73 remained in a vertical position facing } \\
\text { closely the mother/calf pair, while the juvenile } \\
\text { joined him. }\end{array}$ \\
\hline $05: 16$ to $05: 22$ & & $\begin{array}{l}\text { The mother was caught between Ta\# } 73 \\
\text { vertically and the juvenile horizontally and } \\
\text { attempted to escape accelerating away. Then, } \\
\text { Ta\# } 73 \text { remained deeper, in a vertical position. } \\
\text { Ta\#305 swam slowly in parallel to the female, } \\
\text { and pointed his rostrum towards the genital } \\
\text { region of the mother, trying to touch it. The } \\
\text { female escaped the contact event turning back } \\
\text { to her offspring. Ta\#305 calmly followed her. }\end{array}$ \\
\hline
\end{tabular}




\begin{tabular}{|c|c|c|}
\hline $05: 22$ to $05: 29$ & & $\begin{array}{l}\text { Ta\#73 surfaced vertically near the mother/ } \\
\text { calf pair and rubbed his rostrum against the } \\
\text { left pectoral fin and then the belly side of the } \\
\text { mother. Ta\# } 305 \text { swam towards the female } \\
\text { horizontally, and finally reached her. The } \\
\text { two males (Ta\# } 305 \text { horizontally and Ta\# } 73 \\
\text { vertically) turned simultaneously behind the } \\
\text { female, who tried to escape and came back } \\
\text { near her calf. Ta\#305 swam away lying on his } \\
\text { right flank and defecated. Ta\# } 73 \text { remained into } \\
\text { a deeper vertical posture, pointing his rostrum } \\
\text { towards the female. }\end{array}$ \\
\hline $05: 37$ to $05: 39$ & & $\begin{array}{l}\text { Ta\#305 came back through the mother. Ta\# } 73 \\
\text { displayed his ventral side-up, behind the } \\
\text { mother. The juvenile lied on his left flank, in a } \\
\text { echelon position, beneath Ta\# } 73 \text {. }\end{array}$ \\
\hline $05: 53$ to $05: 58$ & \multirow{5}{*}{$\begin{array}{l}\text { Phase } V \text { « agonistic escalation phase: strong } \\
\text { agonistic and weak socio-sexual behaviours } \\
\text { phase »Burst pulses emission frequency }=28.2 \\
\mathrm{BP} / \mathrm{min} \text {. }\end{array}$} & $\begin{array}{l}\text { Ta\#73 and the juvenile slowly came to the } \\
\text { female in an echelon position. Ta\#305 faced } \\
\text { her, and rubbed his flank against her's, crossing } \\
\text { her. The female ran back to her calf. The } \\
\text { echelon-position Ta\# } 73 / \text { juvenile pair turned } \\
\text { around the female in the opposite side. }\end{array}$ \\
\hline $05: 58$ to $05: 59$ & & $\begin{array}{l}\text { The mother joined his calf. Ta\# } 305 \text { swam fastly } \\
\text { to her and pointed his rostrum towards her } \\
\text { belly side. He charged her and pushed her left } \\
\text { flank with his rostrum. Ta\# } 73 \text { surfaced near } \\
\text { the female at the same moment and pointed } \\
\text { his head towards the female. The mother was } \\
\text { then blocked between the two adult males. The } \\
\text { juvenile remained away from the group. }\end{array}$ \\
\hline $05: 59$ to $06: 04$ & & $\begin{array}{l}\text { The female managed to escape and reached } \\
\text { her calf. Ta\#73 swam and pointed his rostrum } \\
\text { towards her. The juvenile stayed farther } \\
\text { behind Ta\#73, always in echelon position. } \\
\text { Ta\# } 73 \text { opened his jaws, trying to bite the } \\
\text { mother's dorsal fin, who managed to escape, } \\
\text { circumventing him. The female joined the calf } \\
\text { and carried him to the surface on her head. }\end{array}$ \\
\hline $06: 04$ to $06: 08$ & & $\begin{array}{l}\text { Ta\#73 and Ta\#305 turned back to the female } \\
\text { from the opposite sides. The juvenile followed } \\
\text { Ta\# } 73 \text { and remained on the sidelines. While } \\
\text { the two adult males came closer to the female } \\
\text { on both sides, she accelerated away from her } \\
\text { calf. Ta\# } 305 \text { kept pursuing her. The mother } \\
\text { crossed the juvenile who faced her. The mother } \\
\text { circumvented the juvenile who prevented her } \\
\text { to turn towards her calf. Ta\#73 reached the } \\
\text { neonate. }\end{array}$ \\
\hline $06: 08$ to $06: 10$ & & $\begin{array}{l}\text { The juvenile rubbed his head against the } \\
\text { genital area of the mother who finally managed } \\
\text { to fastly join her calf. Ta\# } 305 \text { pointed his } \\
\text { rostrum towards her and swam to her. Ta\# } 73 \\
\text { joined her on the opposite side. }\end{array}$ \\
\hline
\end{tabular}




\section{References}

1. Bearzi M (2005) Dolphin sympatric ecology. Marine Biology Research 1(3): 165.

2. Norris KS, Dohl TP (1980) The structure and functions of cetacean schools. In: Herman LM (Ed.), Cetacean behaviour: Mechanisms and functions. John Wiley \& Sons, New York, USA, pp. 211-261.

3. Stensland E, Angerbjoern A, Berggren P (2003) Mixed species groups in mammals. Mammal Review 33(3-4): 205-223.

4. Baird RW (1998) An interaction between Pacific white-sided dolphins and a neonatal harbor porpoise. Mammalia 62(1): 129-133.

5. Dunn DG, Barco SG, Pabst DA, McLellan WA (2002) Evidence for infanticide in bottlenose dolphins of the western north Atlantic. J Wildl Dis 38(3): $505-510$

6. Patterson IA, Reid RJ, Wilson B, Grellier K, Ross HM, et al. (1998) Evidence for infanticide in bottlenose dolphins: An explanation for violent interactions with harbour porpoises? Proc Biol Sci 265(1402): 1167-1170.

7. Ross HM, Wilson B (1996) Violent interactions between bottlenose dolphins and harbour porpoises. Proceedings of the Royal Society of London B: Biological Sciences 263(1368): 283-286.

8. Clua E, Grosvalet F (2001) Mixed-species feeding aggregation of dolphins, large tunas and seabirds in the Azores. Aquatic Living Resources 14(1): 11-18.

9. Hrdy SB, Hausfater G (1984) Comparative and evolutionary perspectives on infanticide: Introduction and overview. In: Hausfater G, Hrdy SB (Eds.), Infanticide: Comparative and evolutionary perspectives ( $4^{\text {th }}$ edn), Aldine Transaction, New York, USA, pp. 13-35.

10. Jefferson TA, Stacey PJ, Baird RW (1991) A review of killer whale interactions with other marine mammals: Predation to coexistence. Mammal Review 21(4): 151-180.

11. Shane SH (1995) Relationship between pilot whales and Risso's dolphins at Santa Catalina Island, California, USA. Marine Ecology Progress Series, Oldendorf, Germany 123(1): 5-11.

12. Spitz J, Rousseau Y, Ridoux V (2006) Diet overlap between harbour porpoise and bottlenose dolphin: An argument in favour of interference competition for food? Estuarine, Coastal and Shelf Science 70(1-2): 259-270.

13. Wolff JO (1997) Population regulation in mammals: An evolutionary perspective. Journal of Animal Ecology 66(1): 1-13.

14. Brown DH, Norris KS (1956) Observations of captive and wild cetaceans. Journal of Mammalogy 37(3): 311-326.

15. Caldwell MC, Caldwell DK (1966) Epimeletic (care-giving) behaviour in Cetacea. In: Norris KS (Eds.), Whales, dolphins and porpoises. University of California Press, Berkeley, California, USA, pp. 755-789.

16. Norris KS, Prescott J (1961) Observations on Pacific cetaceans of Californian and Mexican waters. University of California Publications in Zoology 63: 291-401.

17. Fagen R (1981) Animal Play Behaviour. Oxford University Press, New York, USA.

18. Hall SL (1999) Object play by adult animals. In: Bekoff LM, Byers JA (Eds.), Animal play. Evolutionary, Comparative and Ecological Perspectives. Cambridge University Press, Cambridge, United Kingdom, pp. 27-44.

19. Le Boeuf BL, Campagna C (1994) Protection and abuse of young in pinnipeds. In: Parmigiani S, Vom Saal F (Eds.), Infanticide and parental care. Harwood Academic Publishers, London, United Kingdom, pp. 257-276.
20. Rose NA, Deutsch CJ, Le Bœuf BJ (1991) Sexual behaviour of male northern elephant seals. III. The mounting of weaned pups. Behaviour 119(3-4): 171-192.

21. Herzing DL (1996) Vocalizations and associated underwater behaviour of free-ranging Atlantic spotted dolphins, Stenella frontalis and bottlenose dolphins, Tursiops truncatus. Aquatic Mammals 22(2): 61-79.

22. Herzing DL, Johnson CM (1997) Interspecific interactions between Atlantic spotted dolphins (Stenella frontalis) and bottlenose dolphins (Tursiops truncatus) in the Bahamas, 1985-1995. Aquatic Mammals 23(2): 85-99.

23. Hrdy SB (1979) Infanticide among animals: A review, classification, and examination of the implications for the reproductive strategies of females. Ethology and Sociobiology 1(1): 13-40.

24. Barnett J, Davison N, Deaville R, Monies R, Loveridge J, et al. (2009) Post mortem evidence of interactions of bottlenose dolphins (Tursiops truncatus) with other dolphin species in south-west England. Vet Rec 165(15): 441-444.

25. Kaplan JD, Lentell BJ, Lange W (2009) Possible evidence for infanticide among bottlenose dolphins (Tursiops truncatus) off St. Augustine, Florida. Marine Mammal Science 25(4): 970-975

26. Larrat S, Measures LN, Lair S (2012) Rake Marks on a Harbor Porpoise (Phocoena phocoena) Calf Suggestive of a Fatal Interaction with an Atlantic White-Sided Dolphin (Lagenorhynchus acutus). Aquatic Mammals 38(1): 86-91.

27. Robinson KP (2014) Agonistic intraspecific behaviour in free-ranging bottlenose dolphins: Calf-directed aggression and infanticidal tendencies by adult males. Marine Mammal Science 30(1): 381-388.

28. Wedekin LL, Daura-Jorge FG, Simoes-Lopes PC (2004) An aggressive interaction between bottlenose dolphins (Tursiops truncatus) and estuarine dolphins (Sotalia guianensis) in southern Brazil. Aquatic Mammals 30(3): 391-397.

29. Connor RC, Wells RS, Mann J, Read AJ (2000) The bottlenose dolphin: Social Relationships in a Fission-Fusion Society. In: Mann J, Connor RC, Tyack PL, Whitehead H (Eds.), Cetacean societies: Field studies of dolphins and whales. The University of Chicago Press, Chicago, Illinois, USA, pp. 91-126.

30. Dulau-Drouot V, Boucaud V, Rota B (2008) Cetacean diversity off La Réunion Island (France). Journal of the Marine Biological Association of the United Kingdom 88(6): 1263-1272.

31. Condet M, Dulau-Drouot V (2016) Habitat selection of two islandassociated dolphin species from the south-west Indian Ocean. Continental Shelf Research 125: 18-27.

32. Geraci JR, Lounsbury VJ, Yates N (2005) Marine mammals ashore: A field guide for strandings ( $2^{\text {nd }}$ edn), National Aquarium in Baltimore, Baltimore, USA.

33. Altmann J (1974) Observational study of behaviour: Sampling methods. Behaviour 49(3): 227-267.

34. Hauser MD, Nelson DA (1991) 'Intentional' signaling in animal communication. Trends in Ecology and Evolution 6(6): 186-189.

35. Maynard Smith J (1974) The theory of games and the evolution of animal conflicts. J Theor Biol 47(1): 209-221.

36. Shane SH, Wells RS, Würsig B (1986) Ecology, behaviour and social organization of the bottlenose dolphin: A review. Marine Mammal Science 2(1): 34-63.

37. Samuels A, Gifford T (1997) A quantitative assessment of dominance relations among bottlenose dolphins. Marine Mammal Science 13(1): 70-99. 
38. Overstrom NA (1983) Association between burst-pulse sounds and aggressive behaviour in captive Atlantic bottlenosed dolphins (Tursiops truncatus). Zoo Biology 2(2): 93-103.

39. Janik VM, King SL, Sayigh LS, Wells RS (2013) Identifying signature whistles from recordings of groups of unrestrained bottlenose dolphins (Tursiops truncatus). Marine Mammal Science 29(1): 109-122.

40. Lilly JC, Miller AM (1961) Vocal exchanges between dolphins. Science 134(3493): 1873-1876.

41. Murray SO, Mercado E, Roiblat HL (1998) Characterizing the graded structure of false killer whale (Pseudorca crassidens) vocalizations. J Acoust Soc Am 104(3 Pt 1): 1679-1688.

42. Watkins WA (1967) The harmonic interval: Fact or artifact spectral analysis of pulse trains. In: Tavolga WN (Ed.), Marine Bio-Acoustics. Pergamon Press, Oxford, United Kingdom 2: pp. 15-43.

43. Perrin WF, Holts DB, Miller RB (1977) Growth and reproduction of eastern spinner dolphin, a geographical form of Stenella longirostris in eastern tropical Pacific. Fishery Bulletin 75(4): 725-750.

44. Cramer K, Perryman WL (2002) Estimation of reproductive and demographic parameters of the eastern spinner dolphin (Stenella longirostris orientalis) using aerial photography (NMFS Administrative Report LJ-02-31). La Jolla, Southwest Fisheries Science Center, NMFS, California, USA.

45. Bearzi G, Notarbartolo-Di-Sciara G, Politi E (1997) Social ecology of bottlenose dolphins in the Kvarneric (northern Adriatic Sea). Marine Mammal Science 13(4): 650-668

46. Johnson CM, Norris KS (1994) Social behaviour. In: Norris KS, Würsig B, Wells RS, Würsig M (Eds.), The Hawaiian spinner dolphin. University of California Press, Berkeley, California, USA, pp. 243-286.

47. Tavolga MC (1966) Behaviour of the bottlenose dolphin (Tursiops truncatus): social interactions in a captive colony. In: Norris KS (Eds.), Whales, dolphins and porpoises. University of California Press, Berkeley, California, USA, pp. 718-730.

48. Blomqvist C, Amundin M (2004) High-frequency burst-pulse sounds in agonistic/aggressive interactions in bottlenose dolphins (Tursiops truncatus). In: Thomas JA, Moss CF, Vater M (Eds.), Echolocation in bats and dolphins. The University of Chicago Press, Chicago, Illinois, USA pp. 425-431.

49. Defran RH, Pryor K (1980) The behaviour and training of cetaceans in captivity. In: Herman LM (Ed.), Cetacean behaviour: Mechanisms and functions. John Wiley \& Sons, New York, USA, pp. 319-362.

50. Blomqvist C, Amundin M (2004) An acoustic tag for recording directional pulsed ultrasounds aimed at free-swimming bottlenose dolphins (Tursiops truncatus) by conspecifics. Aquatic Mammals 30(2): 345-356.

51. Herman LM, Tavolga WN (1980) Communication systems of Cetaceans In: Herman LM (Eds.), Cetacean behaviour: Mechanisms and functions. (pp. 149-197). John Wiley \& Sons, New York, USA.

52. Paulos RD (2004) Non-vocal communication in the Atlantic spotted dolphin and the Indo-Pacific bottlenose dolphin. University of Southern Mississippi, Hattiesburg, USA.

53. Pryor K (1990) Non-acoustic communication in small cetaceans: Glance, touch, position, gesture, and bubbles. In: Thomas JA, Kastelein RA (Eds.), Sensory Abilities of Cetaceans. Laboratory and Field Evidence. Plenum Press, New York, USA, pp. 537-543.

54. Dudzinski KM (1996) Communication and behaviour in the Atlantic spotted dolphins (Stenella frontalis): Relationships between vocal and behavioural activities (Doctoral dissertation, Texas A\&M University).

55. Mann J, Smuts B (1999) Behavioural development in wild bottlenose dolphin newborns (Tursiops sp.). Behaviour 136(5): 529-566.
56. Östman J (1991) Changes in aggressive and sexual behaviour between two male bottlenose dolphins (Tursiops truncatus) in a captive colony. In: Pryor K, Norris KS (Eds.), Dolphin societies, Discoveries and Puzzles. University of California Press, Berkeley, California, USA, pp. 305-318.

57. Weaver A (2003) Conflict and reconciliation in captive bottlenose dolphins, Tursiops truncatus. Marine Mammal Science, 19(4): 836-846.

58. Connor RC, Read AJ, Wrangham R (2000) Male reproductive strategies and social bonds. In: Mann J, Connor RC, Tyack PL, \& Whitehead H (Eds.), Cetacean Societies: Field Studies of Dolphins and Whales. The University of Chicago Press, Chicago, Illinois, USA, pp. 247-269.

59. Tavolga C, Essapian FS (1957) The behaviour of bottle-nosed dolphins (Tursiops truncatus): Mating, pregnancy, parturition and motherinfant behaviour. Zoologica 42: 11-31.

60. Würsig B, Würsig M (1979) Behaviour and ecology of the bottlenose dolphin, Tursiops truncatus, in the South Atlantic. US Fisheries Bulletin 77(2): 399-412.

61. Dudzinski KM (1998) Contact behaviour and signal exchange among Atlantic spotted dolphins (Stenella frontalis). Aquatic Mammals 24(3): 129-142.

62. Saayman GS, Tayler CK (1973) Social organization of inshore dolphins (Tursiops aduncus and Sousa) in the Indian Ocean. Journal of Mammalogy 54(4): 993-996.

63. Connor RC, Smolker RA (1996) "Pop" goes the dolphin: A vocalization male bottlenose dolphins produce during consortships. Behaviour 133(9): 643-662.

64.Würsig B, Kieckhefer TR, Jefferson TA (1990) Visual displays for communication in cetaceans. In: Thomas JA, Kastelein RA (Eds.) Sensory Abilities of Cetaceans. Laboratory and Field Evidence. Plenum Press, New York, USA, pp. 545-559.

65. Krebs JR, Davies NB (1993) Introduction to behavioural ecology (4 $4^{\text {th }}$ edn), John Wiley \& Sons, Oxford, United Kingdom.

66. Jepson PD, Baker JR (1998) Bottlenosed dolphins (Tursiops truncatus) as a possible cause of acute traumatic injuries in porpoises (Phocoena phocoena). Vet Rec 143(22): 614-615.

67. Perrin WF, Gilpatrick JW (1994) Spinner dolphins, Stenella longirostris (Gray, 1828). In: Ridgway SH, Harrison R (Eds.), Handbook of marine mammals, Academic Press, London, United Kigdom, 5: pp. 99-128.

68. Shirakihara M, Yoshida H, Shirakihara K (2003) Indo-Pacific bottlenose dolphins Tursiops aduncus in Amakusa, western Kyushu, Japan. Fisheries Science 69(3): 654-656.

69. MacLeod CD (1998) Intraspecifc scarring in odontocete cetaceans: An indicator of male "quality" in aggressive social interactions? Journal of Zoology 244(1): 71-77

70. Norris KS (1967) Aggressive behaviour in cetacea. In: Clemente CD, Lindsley DB (Eds.), Aggression and Defense: Neural Mechanisms and Social Patterns. University of California Press, Berkeley, California, USA, pp. 225-241.

71. Cockcroft VG, Sauer W (1990) Observed and inferred epimeletic (nurturant) behaviour in bottlenose dolphins. Aquatic Mammals 16(1): 31-32.

72. Cremer MJ, Hardt FAS, Junior AJT (2006) Evidence of epimeletic behaviour involving a Pontoporia blainvillei calf (Cetacea, Pontoporidae). Biotemas 19(2): 83-86.

73. de Moura JF, da Silva Rodrigues E, Siciliano S (2009) Epimeletic behaviour in rough-toothed dolphins (Steno bredanensis) on the east coast of Rio de Janeiro State, Brazil. Marine Biodiversity Records 2(1): e12.

74. Fertl D, Schiro A (1994) Carrying of dead calves by free-ranging Texas 
bottlenose dolphins (Tursiops truncatus). Aquatic Mammals 20(1): 5356.

75. Félix F (1994) A case of epimeletic behaviour in a wild bottlenose dolphin Tursiops truncatus in the Gulf of Guayaquil, Ecuador Investigations on Cetacea 25: 227-234.

76. Connor RC, Smolker RA (1990) Quantitative description of a rare behavioural event: A bottlenose dolphin's behaviour toward her deceased offspring. In: Leatherwood S, Reeves RR (Eds.), The bottlenose dolphin. Academic Press, New York, USA, pp. 355-360.

77. Herzen S, dos Santos ME (1992) Three encounters with wild bottlenose dolphins (Tursiops truncatus) carrying dead calves. Aquatic Mammals 18(2): 49-55.

78. Lodi L (1992) Epimeletic behaviour of free-ranging rough-toothed dolphins, Steno bredanensis, from Brazil. Marine Mammal Science 8(3): 284-287.

79. Mann J, Barnett H (1999) Lethal tiger shark (Galeocerdo cuvier) attack on bottlenose dolphin (Tursiops sp.) calf: Defense and reactions by the mother. Marine Mammal Science 15(2): 568-575.

80. Pilleri G (1984) Epimeletic behaviour in Cetacea: Intelligent or instinctive. Investigations on Cetacea 16: 30-48.

81. Acevedo-Guiterrez A, Dibaradinis A, Larkin S, Larkin K, Forestell, P (2005) Social interactions between tucuxis and bottlenose dolphins in Gandoca-Manzanillo, Costa Rica. Latin American Journal of Aquatic Mammals 4(1): 49-54.

82. Corkeron PJ (1990) Aspects of the behavioural ecology of inshore dolphins Tursiops truncatus and Sousa chinensis in Moreton Bay, Australia. In: Leatherwood S, Reeves RR (Eds.), The bottlenose dolphin. Academic Press, New York, USA, pp. 285-293.

83. Coscarella MA, Crespo EA (2009) Feeding aggregation and aggressive interaction between bottlenose (Tursiops truncatus) and Commerson's dolphins (Cephalorhynchus commersonii) in Patagonia, Argentina. Journal of Ethology 28: 183-187.

84. Cusick JA, Herzing DL (2014) The Dynamic Of Aggression: How Individual And Group Factors Affect The Long-Term Interspecific Aggression Between Two Sympatric Species Of Dolphin. Ethology 120(3): 287-303.

85. Flores PAC, Fontoura NF (2006) Ecology of marine tucuxi, Sotalia guianensis, and bottlenose dolphin, Tursiops truncatus, in Baía Norte, Santa Catarina state, southern Brazil. Latin American Journal of Aquatic Mammals 5(2): 105-115.

86. Connor RC, Smolker RA, Richards AF (1992) Dolphin alliances and coalitions. In: Harcourt AH \& de Wall FBM (Eds.), Coalitions and Alliances in Humans and Other Animals. Oxford University Press, Oxford, United Kingdom, 362(1480): 587-602.

87. Connor RC, Smolker RA, Richards AF (1992) Two levels of alliance formation among male bottlenose dolphins (Tursiops sp.). Proc Nat Acad Sci USA 89(3): 987-990.

88. Scott EM, Mann J, Watson-Capps JJ, Sargeant BL, Connor RC (2005) Aggression in bottlenose dolphins: Evidence for sexual coercion, malemale competition, and female tolerance through analysis of toothrake marks and behaviour. Behaviour 142(1): 21-44.

89. Smolker RA, Richards F, Connor RC, Pepper JW (1992) Sex differences in patterns of association among Indian Ocean bottlenose dolphins. Behaviour 123(1-2): 38-69.

90. McCowan B, Reiss D (1995) Maternal aggressive contact vocalizations in captive bottlenose dolphins (Tursiops truncatus): wide-band, low frequency signals during mother/aunt-infant interactions. Zoo Biology 14(4): 293-309.

91. Dawson SM (1991) Clicks and communication-the behavioural and social contexts of Hector dolphin vocalizations. Ethology 88(4): 265276.

92. Herzing DL (2000) Acoustics and social behaviour of wild dolphins: Implications for a sound society. In: $\mathrm{Au}$ WWL, Popper, AN, Fay RR (Eds.), Hearing by whales and dolphins ( $\left.2^{\text {nd }} e d n\right)$, Springer-Verlag, New York, USA, pp. 225-272.

93. Lammers MO, Au WWL, Herzing DL (2003) The broadband social acoustic signaling behaviour of spinner and spotted dolphins. Journal of the Acoustical Society of America 114: 1629-1639.

94. Lammers MO, Schotten M, Au WWL (2004) The spatial context of freeranging Hawaiian spinner dolphins (Stenella longirostris) producing acoustic signals. Journal of the Acoustical Society of America 116 2615-2615.

95. Perrtree RM, Sayigh LS, Williford A, Bocconcelli A, Curran MC, et al. (2015) First observed wild birth and acoustic record of a possible infanticide attempt on a common bottlenose dolphin (Tursiops truncatus). Marine Mammal Science 32(1): 376-385.

96. Lammers MO, Au WWL, Aubauer R, Nachtigal PE (2004) A comparative analysis of the pulsed emissions of free-ranging Hawaiian spinner dolphins (Stenella longirostris). In: Thomas JA, Moss CF, Vater M (Eds.), Echolocation in bats and dolphins. The University of Chicago Press, Chicago, Illinois, pp. 414-418.

97. Gridley T, Nastasi A, Kriesell HJ, Elwen SH (2015) The acoustic repertoire of wild common bottlenose dolphins (Tursiops truncatus) in Walvis Bay, Namibia. Bioacoustics 24(2): 153-174.

98. Hawkins ER (2010) Geographic variations in the whistles of bottlenose dolphins (Tursiops aduncus) along the east and west coasts of Australia. J Acoust Soc Am 128(2): 924-935.

99. Morisaka T, Shinohara M, Nakahara F, Akamatsu T (2005) Geographic variations in the whistles among three Indo-Pacific bottlenose dolphin Tursiops aduncus populations in Japan. Fisheries Science 71(3): 568576.

100. Wang D, Würsig B, Evans WE (1995) Comparisons of whistles among seven odontocete species. In: Kastelein RA, Thomas JA \& Nachtigall PE (Eds.), Sensory Systems of Aquatic Mammals. De Spil Publishers, Woerden, Netherlands, pp. 299-324.

101. Wang D, Würsig B, Evans WE (1995) Whistles of bottlenose dolphins: Comparisons among populations. Aquatic Mammals 21(1): 65-77.

102. Bazúa-Durán C, Au WL (2002) The whistles of Hawaiian spinner dolphins. J Acoust Soc Am 112(6): 3064-3072.

103. Bazúa-Durán C, Au WL (2004) Geographic variations in the whistles of spinner dolphins (Stenella longirostris) of the Main Hawai'ian Islands. J Acoust Soc Am 116(6): 3757-3769.

104. Norris KS, Würsig B, Wells RS, Würsig M (1994) The Hawaiian Spinner Dolphin. University of California Press, Berkeley, California, USA.

105. Oswald JN, Barlow J, Norris TF (2003) Acoustic identification of nine delphinid species in the eastern tropical Pacific Ocean. Marine Mammal Science 19(1): 20-37.

106. dos Santos ME, Louro S, Couchinho M, Brito C (2005) Whistles of bottlenose dolphins (Tursiops truncatus) in the Sado Estuary, Portugal: Characteristics, production rates, and long-term contour stability. Aquatic Mammals 31(4): 453-462.

107. Hawkins ER, Gartside DF (2009) Patterns of whistles emitted by wild Indo-Pacific bottlenose dolphins (Tursiops aduncus) during a provisioning program. Aquatic Mammals 35(2): 171-186.

108. Caldwell MC, Caldwell DK (1965) Individualized whistle contours in bottlenose dolphins, Tursiops truncatus. Nature 207: 434-435. 
109. Caldwell MC, Caldwell DK, Tyack PL (1990) Review of the signaturewhistle hypothesis for the Atlantic bottlenose dolphin. In: Leatherwood S, Reeves RR (Eds.), The bottlenose dolphin. Academic Press, New York, USA, pp. 199-234.

110. Janik VM, Sayigh LS, Wells RS (2006) Signature whistle shape conveys identity information to bottlenose dolphins. Proceedings of the National Academy of Sciences 103(21): 8239-8297.

111. Janik VM, Slater PJ (1998) Context-specific use suggests that bottlenose dolphin signature whistles are cohesion calls. Anim Behav 56(4): 829-838.

112. Tyack PL (1997) Development and social functions of signature whistles in bottlenose dolphins Tursiops truncatus. Bioacoustics 8(12): 21-46.

113. Janik VM, Dehnhardt G, Todt D (1994) Signature whistle variations in a bottlenose dolphin, Tursiops truncatus. Behavioural Ecology and Sociobiology 35(4): 243-248.

114. Tyack PL (2003) Dolphins communicate about individual-specific social relationships. In: de Waal FBM, Tyack PL (Eds.), Animal social complexity: Intelligence, culture and individualized societies. Harvard University Press, Cambridge, Massachusetts, USA, pp. 342 361.

115. Watwood SL, Owen ECG, Tyack PL, Wells RS (2005) Signature whistle use by temporarily restrained and free-swimming bottlenose dolphins Tursiops truncatus. Animal Behaviour 69: 1373-1386.

116. Breden F, Hausfater G (1990) Selection within and between social groups for infanticide. American Naturalist 136(5): 673-688.

117. Darwin C (1871) The descent of man and selection in relation to sex $\left(2^{\text {nd }}\right.$ edn), Wallachia Publishers, New York, USA

118. Ebensberger LA (1998) Strategies and counterstrategies to infanticide in mammals. Biological Review 73(3): 321-346.

119. van Schaik CP (2000) Infanticide by male primates: the sexual selection hypothesis revisited. In: van Schaik CP, Janson CH (Eds.), Infanticide by males. Cambridge University Press, Cambridge, United Kingdom, pp. 27-60.

120. Connor RC, Richards AF, Smolker RA, Mann J (1996) Patterns of female attractiveness in Indian Ocean bottlenose dolphins. Behaviour 133(1-20: 37-69.

121. Cotter MP, Maldini D, Jefferson TA (2012) "Porpicide" in California: Killing of harbor porpoises (Phocoena phocoena) by coastal bottlenose dolphins (Tursiops truncatus). Marine Mammal Science 28(1): E1-E15.

122. Herzing DL, Elliser CR (2013) Directionality of sexual activities during mixed species encounters between Atlantic spotted dolphin (Stenella frontalis) and bottlenose dolphin (Tursiops truncatus).
International Journal of Comparative Psychology 26: 124-134.

123. Herzing DL, Moewe K, Brunnick BJ (2003) Interspecies Interactions Between Atlantic Spotted Dolphins, Stenella Frontalis And Bottlenose Dolphins, Tursiops Truncatus, On Great Bahamas Bank, Bahamas. Aquatic Mammals 29(3): 335-341.

124. Crossman CA, Taylor EB, Barrett-Lennard LG (2016) Hybridization in the Cetacea: widespread occurrence and associated morphological, behavioural, and ecological factors. Ecol Evol 6(5): 1293-1303.

125. Fraser FC (1940) Three anomalous dolphins from Blacksod Bay, Ireland. Proceedings of the Royal Irish Academy 45: 413-460.

126. Miyazaki N, Hirosaki Y, Kinuta T, Omura H (1992) Osteological Study of a hybrid between Tursiops truncatus and Grampus griseus. Bull Natn Sci Mus Tokyo SerA 18(2): 79-94.

127. Nishiwaki M, Tobayama T (1982) Morphological study on the hybrid between Tursiops and Pseudorca. Scientific Reports of the Whales Research Institute 34: 109-121.

128. Shimura E, Numachi K, Sezaki K, Hirosaki Y, Watabe S, Hashimoto K (1986) Biochemical evidence of hybrid formation between the two species of dolphin, Tursiops truncatus and Grampus griseus. Bulletin of the Japanese Society for the Science of Fish 52: 725-730.

129. Zhang P, Han J, Lu Z, Chen R (2014) Molecular Evidence of a CaptiveBorn Intergeneric Hybridization Between Bottlenose and Risso's Dolphins: Tursiops truncatus $\times$ Grampus griseus. Aquatic Mammals 40(1): 5-8.

130. Kellar NM, Trego ML, Marks CI, Chivers SJ, Danil K, et al. (2009) Blubber testosterone: A potential marker of male reproductive status in short-beaked common dolphins. Marine Mammal Science 25(3): 507-522.

131. Schroeder JP, Keller KV (1989) Seasonality of serum testosterone levels and sperm density in Tursiops truncatus. J Exp Zool 249(3): 316-321.

132. Best PB (2007) Whales \& Dolphins of the Southern African Subregion Cambridge University Press, Cape Town, South Africa.

133. Gibson QA, Mann J (2008) Early social development in wild bottlenose dolphins: Sex differences, individual variation and maternal influence. Animal Behaviour 76: 375-387.

134. Mann J (2006) Establishing Trust: Sociosexual behaviour and the development of male-male bonds among Indian Ocean bottlenose dolphin calves. In: Vasey P, Sommer V (Eds.), Homosexual Behaviour in Animals: An Evolutionary Perspective. University Press, Cambridge, New York, USA, pp. 107-130.

135. Gilmartin WG, Eberhardt LL (1995) Status of the Hawaiian Monk Seal population. Canadian Journal of Zoology 73(6): 1185-1190.

Your next submission with Juniper Publishers
will reach you the below assets
- Quality Editorial service
- Swift Peer Review
- Reprints availability
- E-prints Service
- Manuscript Podcast for convenient understanding
- Global attainment for your research
- Manuscript accessibility in different formats
( Pdf, E-pub, Full Text, Audio)
- Unceasing customer service
Track the below URL for one-step submission
https://juniperpublishers.com/online-submission.php

